\title{
Can Diffusive Gradients in Thin Films (DGT) Technique and Chemical Extraction Methods Successfully Predict both Zn Bioaccumulation Patterns in Plant and Leaching to Groundwater in Soils Amended with Engineered ZnO Nanoparticles?
}

\author{
Patricia Almendros ${ }^{1}$ (D) - Demetrio González ${ }^{1}$ (D) - Miguel A. Ibañez ${ }^{2}$ (D) $\cdot$ María Dolores Fernández $^{3}$ (D) \\ Concepción García-Gomez ${ }^{3}$ (D) - Erik Smolders ${ }^{4}$ (D) - Ana Obrador ${ }^{1}$ (D)
}

Received: 2 December 2019 / Accepted: 26 March 2020

(C) Sociedad Chilena de la Ciencia del Suelo 2020

\begin{abstract}
The interactions of nanoparticles (NPs) with different soil components have impact on their fate, transport, and behavior. The present study was conducted to find operational extraction procedures for effective assessment of both plant availability and leaching to groundwater of $\mathrm{Zn}$ applied to soils from zinc oxide $(\mathrm{ZnO})$ NPs. A greenhouse experiment was performed in lysimeters with different $\mathrm{ZnO}-\mathrm{NPs}$ amounts (3, 20, and $225 \mathrm{mg} \mathrm{Zn} \mathrm{kg}^{-1}$ ) in two typical soils in Central Spain. The experiment was carried out spanning the whole plant life-cycle of cherry tomato and common bean. The soil extractable $\mathrm{Zn}$ amounts were measured using chemical extraction procedures (the rhizosphere-based low-molecular-weight organic acids-LMWOAs-, $\mathrm{CaCl}_{2}$, DTPA-TEA, water-soluble-WS- and $\mathrm{NH}_{4} \mathrm{Ac}$ ) and the diffuse gradients in thin films (DGT) technique. The regression studies between extractable $\mathrm{Zn}$ concentrations and $\mathrm{Zn}$ concentrations in plant tissues showed that $\mathrm{LMWOAs}, \mathrm{CaCl}_{2}, \mathrm{WS}$, and the DGT technique successfully predicted Zn concentrations in all the different parts of plants. The prediction capacity of the DTPATEA and $\mathrm{NH}_{4} \mathrm{Ac}$ approaches were strongly influenced by soil type and plant species. LMWOAs, $\mathrm{CaCl}_{2}$, WS, and the DGT technique were the most robust approaches for evaluation of $\mathrm{Zn}$ bioavailability from the soils treated with ZnO-NP. Although LMWOAs and WS reagents were also able to estimate the total quantities of $\mathrm{Zn}$ that were leached to groundwater, the correlation improved when soil type was included as a categorical variable. DTPA-TEA and $\mathrm{NH}_{4} \mathrm{Ac}$ were able to predict the $\mathrm{Zn}$ concentrations in the plant tissues only if soil type was considered as a categorical factor.
\end{abstract}

Keywords Zinc $\cdot$ Nanoparticles $\cdot$ LMWOAs $\cdot$ DGT $\cdot$ Traditional chemical extraction

Headings $\mathrm{CaCl}_{2}$, LMWOAs, WS, and DGT-technique estimated the $\mathrm{Zn}$ concentration in plant from $\mathrm{ZnO}$ NPs in soil

The weak extractants and DGT technique offered the most robust approaches

DTPA-TEA and $\mathrm{NH}_{4} \mathrm{Ac}$ regression models improve with soil type as a categorical variable

Electronic supplementary material The online version of this article (https://doi.org/10.1007/s42729-020-00241-x) contains supplementary material, which is available to authorized users.

Patricia Almendros

p.almendros@upm.es

1 Chemical and Food Technology Department, CEIGRAM, Research Centre for the Management of Agricultural and Environmental Risks, Universidad Politécnica de Madrid (UPM), Av. Puerta de Hierro, 2, 28040 Madrid, Spain
2 Departamento de Economía Agraria, Estadística y Gestión de Empresas, Universidad Politécnica de Madrid (UPM), Ciudad Universitaria. Avda. Complutense s/n, 28040 Madrid, Spain

3 Environment Department, Instituto Nacional de Investigación y Tecnología Agraria y Alimentaria (INIA), Ctra. A Coruña km 7.5, 28040 Madrid, Spain

4 Division of Soil and Water Management, K.U. Leuven, Kasteelpark Arenberg 20, B-3001 Leuven, Belgium 


\section{Introduction}

The use of engineered nanoparticles (NPs) in agriculture has created great interest as they have an enormous range of potential applications in this sector, including in agrochemical formulations such as pesticides and fertilizers (Montalvo et al. 2016; Bastani et al. 2018; Tombuloglu et al. 2019; Adisa et al. 2019). Using NPs would make it possible to reduce the amount of plant protection products applied, minimize nutrient losses in fertilization, and help increase yields through optimized nutrient management (Kopittke et al. 2019; Pandorf et al. 2019; Bala et al. 2019; Adisa et al. 2019). The fact that approximately one third of the world's soils are Zn deficient has implications not only for plant growth and nutrition but also for $\mathrm{Zn}$ concentrations in the edible parts of plants and human $\mathrm{Zn}$ nutrition (Cakmak and Kutman 2018). In relation to this, Zn oxide NPs ( $\mathrm{ZnO} N P s$ ) have been proposed as a possible fertilizer to alleviate $\mathrm{Zn}$ deficiencies in soils (Milani et al. 2012; Adhikari et al. 2015; Lv et al. 2015, 2019; Montalvo et al. 2016).

Over the last decade, both positive and negative effects of metal-based engineered NPs on the growth, yield, and physiology of plants have been widely reported in the literature. Plant responses to metallic and metal oxide NPs vary greatly with plant species (and even ecotypes), growth stages, soil properties, application methods, doses, and durations of NP exposure, as well as the specific surface area and size-related properties of NPs (Ebbs et al. 2016; Kopittke et al. 2019; Poynton et al. 2019; Su et al. 2019; Tortella et al. 2019; Meesters et al. 2019). The interactions of NPs with different soil components have a profound impact on their fate, transport, and behavior (Mitrano et al. 2017; El Hadri et al. 2018; Baddar et al. 2019; Zhao et al. 2019). Natural soils exhibit broader particle size distributions, more irregular grain shapes, greater variations in surface charge, and a larger variety of mineral surface types than synthetic culture media. Engineered NPs applied to soils are subject to physical processes as well as to chemical and biological reactions, and they may be either retained in the solid matrix or mobilized into pore water. Soil moisture content, repeated drying and rewetting cycles, temperature, and especially soil $\mathrm{pH}$ may all have an influence on the rate of the weathering process (Lock and Janssen 2003; Rutkowska et al. 2015). Studies conducted in natural soils and for whole-life cycles are necessary to determine the fate of NPs in the environment and also their behavior in soils and plants (Servin and White 2016; Rizwan et al. 2017).

In most countries, risk assessments and the regulation of contaminants are still mainly based on total concentration threshold values Harmsen $(2007,2008)$. However, the risk of exposure of sensitive receptors to metal-based engineered NPs in soils and their transport to other environmental compartments (such as groundwater) have little relation to their presence, but are highly dependent on their availability and, particularly, their tendency to be transferred into soil pore water (Rodrigues et al. 2016).

To study the environmental fate of classic-sized metals (micrometer size), their availability in soils (whether actual or potential) has often been evaluated using different onestep extraction procedures involving chemical-extracting media of different strengths, including water, buffered (fixed $\mathrm{pH}$ ) and unbuffered (with the $\mathrm{pH}$ of the extractant mainly depending on the soil $\mathrm{pH}$ ) neutral salts, complexing agents, mild acids, and organic compounds. Of these extracting agents, neutral-unbuffered salt solutions (such as $\mathrm{CaCl}_{2}$ or $\mathrm{NaNO}_{3}$ ) are typically used in ion-exchange-based methods because, as they are weak substitution agents, they can be used to evaluate labile fractions through the replacement of their cation. Other extractants, such as buffered salt solutions (e.g. 1.0 M $\mathrm{NH}_{4} \mathrm{OAc} \mathrm{pH}=7.0$ ) and complexing agents (e.g. ethylenediaminetetraacetic acid-EDTA - and diethylene triaminepentaacetic acid-DTPA), are frequently applied because of their ability to form very stable water-soluble complexes with a wide range of cations. Other weak extractions that include water (WS) or LMWOAs (low-molecular-weight organic acids) have also often been proposed as tools to assess the availability of metals to plants. Although it is unlikely that these chemical extraction techniques could imitate the process of metal absorption or uptake in living organisms, the application of chemical extraction procedures in soils mainly focuses on assessing the potential availability and mobility of metals, which is related to their soil-plant transfer. This also makes it possible to study their migration within the soil profile, which is usually associated with groundwater problems (Rauret 1998; Menzies et al. 2007; Alvarenga et al. 2013, 2014; De Santiago-Martín et al. 2014; De Santiago-Martin et al. 2015; Karimi et al. 2019).

It is crucial to optimize and validate the operating features of such extraction procedures before their application. Chemical measurements in soils can help to estimate the risk of $\mathrm{Zn}$ accumulation in plants if a correlation between the resulting soil chemical values and plant metal amounts can be demonstrated. The correlation coefficients, $r$, allow an evaluation of the overall prediction of bioavailability. However, these tests will, in many cases, be soil- or site-specific and cannot be extrapolated to other type of soils where other factors may control bioavailability. Generally, the inclusion of soil properties variables improved the correlation coefficients to different extent for different extraction methods (Feng et al. 2005a, b). The soil pH is a key driver of the $\mathrm{Zn}$ solubility (Zhao et al. 2012a, b), and its influence on the availability of ZnO-NPs has been little addressed (Cristina et al. 2015). In relation to this, two typical soils of the Mediterranean area of Central Spain are either acidic soils, which are characteristically low in organic matter, or soils characterized by medium or high calcium carbonate, $\mathrm{pH}$ above 7.5 , and also low organic matter content (Alvarez et al. 2006; Obrador et al. 2007). 
Other approaches employed to estimate bioavailable concentrations of $\mathrm{Zn}$ in soils include the determination of metal contents in soil through the diffusive gradient in thin films (DGT) technique. Since the DGT technique was first described by Davison and Zhang (1994), it has proven to be a useful tool for assessing the bioavailability of metals in soils. The DGT approach is based on Fick's first law of diffusion and is a technique for determining the labile metal/metalloid content in soils. The DGT technique has been widely used for evaluating the environmental impact and bioavailability of various metals $(\mathrm{Cr}, \mathrm{Ni}, \mathrm{Cu}, \mathrm{Zn}, \mathrm{As}$, and $\mathrm{Cd})$, nutrients $(\mathrm{P})$, and other substances (drugs, antibiotics...).

Using the experience and knowledge gained from studies of the chemical availability/mobility of trace metals in soils, similar extraction techniques are now beginning to be used to assess plant availability and leaching to ground water of metals applied to soils from metal-based engineered NPs (Zhao et al. 2012a, b; Antisari et al. 2013; Judy et al. 2015; Gomes et al. 2015; Carbone et al. 2016; Hashimoto et al. 2017). The results obtained from these studies have been contradictory and often inconclusive. The DGT technique has also been suggested as a way to sample an available fraction of metal concentrations in soils amended with metal-based NPs. Although publications on the use of DGT in soils containing NPs (from natural or applied sources) are still extremely limited, it is possible to find some papers in which the DGT method was used when ZnO NPs, Ag NPs, AgCl NPs, or $\mathrm{Ag}_{2} \mathrm{~S}$ NPs were applied to the soil (Sekine et al. 2014; Wang et al. 2016). Plant analysis should be used in combination with soil tests before arriving at any firm recommendations for the use of an extraction method to assess the bioavailability of metals to plants from NPs in soils. To the best of our knowledge, there are no published studies on the selection, comparison, and, of particular importance, the validation of standardized extraction techniques for estimating the pools of metals applied to soils in the form of metal-based NPs that are (either actually or potentially) available for plant uptake and also potentially leachable to groundwater.

In relation to what has been outlined above, the hypothesis of this paper is that operational extraction procedures could be used to assess both the availability of $\mathrm{Zn}$ to plants and the potential risk of $\mathrm{Zn}$ transport to groundwater resulting from leaching after recent applications of $\mathrm{Zn}$, in the form of $\mathrm{ZnO}$ NPs, to soils typical of the Mediterranean area (of central Spain). To investigate this, we conducted a greenhouse experiment, in lysimeters, which spanned the whole plant life-cycle of cherry tomatoes and common beans grown in two soils typical of the Mediterranean area (an acidic soil with a low organic matter content and a calcareous soil characterized by a $\mathrm{pH}$ of above 7.5 and with a medium-to-high calcium carbonate content and a low organic matter content). The specific objectives of our study were (i) to investigate the use of different chemical and DGT extraction protocols and the relationships between the $\mathrm{Zn}$-extractability found in the different $\mathrm{ZnO}$ NPs-amended soils and patterns of $\mathrm{Zn}$ bioaccumulation in plants and (ii) to ascertain whether the total quantities of $\mathrm{Zn}$ that would be leached to groundwater (during the whole plant life-cycle) could be predicted using operational extraction procedures.

\section{Materials and Methods}

\subsection{Nanoparticle Characterization}

$\mathrm{ZnO}$ NPs with a nominal primary particle size of less than $100 \mathrm{~nm}$ (i.e., $\mathrm{rp} \leq 50 \mathrm{~nm}$ ) and a specific surface area of 15 $25 \mathrm{~m} 2 / \mathrm{g}$ (manufacturer's data) were obtained from SigmaAldrich (Germany). The characterization of ZnO NPs particles used in this study is shown in Supplementary Information.

The size and shape of $\mathrm{ZnO}$ NPs were determined at the ICTS Centro Nacional de Microscopía Electrónica under a transmission electron microscope (TEM). A drop of the $\mathrm{ZnO}$ NP suspension in n-butanol was placed onto a carbon-coated copper grid, and the solvent was left to evaporate. Subsequently, samples were observed with TEM (JEM-1400 PLUS) by integrated energy dispersive X-ray (EDX) spectroscopy (Oxford Inca). The mean size and SD of each ZnO NP were calculated by observing $200 \mathrm{ZnO}$ NPs in random view fields. For the nonspherical particles, the longer dimension was measured. For hydrodynamic size, a concentrated suspension of $\mathrm{ZnO}$ NPs (500 mg/L) was prepared in Milli-Q water and dispersed with a homogenizer/disperser (T25 digital ULTRA-TURRAX, IKA®-Werke, Germany, at 100 Wand $40 \mathrm{kHz}$ ) for 20 min to break up agglomerates and to form a homogeneous suspension. The particle size distribution (hydrodynamic diameter) and zeta-potential were determined by a Nano-Zetasizer (1000 HS, Malvern Instrument Ltd., UK), which uses the dynamic light scattering (DLS) technique. The $\mathrm{XRD}$ pattern of this $\mathrm{ZnO}$ was assigned to the hexagonal phase of zincite, while the peaks were sharp, indicating a good crystalline structure (Giri et al. 2007; Perelshtein et al. 2015).

\subsection{Soil Sampling and Characterization}

Soil samples were taken from the Ap horizon $(0-20 \mathrm{~cm})$ of two uncontaminated soils in the Central Spain (Madrid) (Soil 1: $40^{\circ} 44^{\prime} \mathrm{N}, 3^{\circ} 25^{\prime} \mathrm{W}$; and Soil 2: $40^{\circ} 22^{\prime} \mathrm{N}, 3^{\circ} 24^{\prime} \mathrm{W}$ ). Sampling was done at randomly selected points. To avoid potential bias, 30-40 kg were taken from each sampling point and homogenized. Then the soil samples were air-dried and passed through a 2-mm sieve. Both soils were characterized in a previous work using standard analytical determinations (García-Gómez et al. 2017). 
A hydrometric method was used to analyze soil particle size (Day 1965). Soil pH and electrical conductivity were measured in a 1:2.5 and 1:5 (w:v) soil to water, suspension and extract, respectively. The cation exchange capacity (CEC) and available P were determined by the methods described by Bower et al. (1952) and Olsen (1954), respectively, procedure (Nelson and Sommers 1982) while total N was determined by Kjeldhal digestion (Bremner 1996). The total and free $\mathrm{CaCO}_{3}$ contents were determined by the methods presented by Allison and Moodie (1965) and Nijensohn and Pizarro (1960), respectively. Total N content was determined by Kjeldahl method. Soil samples were also digested in a microwave oven with a $1: 1: 1 \mathrm{HNO}_{3} / \mathrm{HF} /$ double deionized water mixture in Teflon bombs to determine total metal contents $(\mathrm{Fe}, \mathrm{Cu}, \mathrm{Mn}$, and $\mathrm{Zn}$ ) in a sample preparation block system (SPB Probe, Perkin-Elmer).

As is usual for uncontaminated soils of the Madrid area (Alvarez et al. 2006; Obrador et al. 2007), both were characterized by low organic matter content $(<2 \%)$. The Soil 1 was acidic $(\mathrm{pH}=5.4)$ with a silt loam texture (USDA) and negligible carbonate content; in contrast, Soil 2 was calcareous $(\mathrm{pH}=8.5$ ) with a silty clay loam texture (USDA). The clay content was significantly higher in the calcareous soil. The total $\mathrm{Zn}$ concentration was higher in Soil 2 $\left(61.8 \mathrm{mg} \mathrm{kg}^{-1}\right)$ than in Soil $1\left(40.1 \mathrm{mg} \mathrm{kg}^{-1}\right)$. The soils were classified as Luvisol and Cambisol (FAO 2015); TypicPalexeralf and TypicHaploxerepts (Soil Survey Staff 2014), respectively. Both types of soils are common in many parts of the Mediterranean area. The main physicochemical properties of both selected soils are shown in the Table 1.

\subsection{Greenhouse Experiment}

A greenhouse experiment was performed in lysimeters in which different amounts of $\mathrm{ZnO}$ NPs were applied in both the acidic and calcareous soils. This study was performed under what can be considered environmentally realistic conditions in order to better understand the real impact of NPs on the environment.

Two different plant species (cherry tomato and common bean) were grown in polyethylene containers (each with a capacity of $10 \mathrm{~L}$, a mean internal diameter of $24 \mathrm{~cm}$, and a height of $24 \mathrm{~cm}$ ). A 1.5 -cm-thick layer of washed gravel and a polyester mesh were placed in the bottom of each lysimeter to facility aeration and drainage, and $10 \mathrm{~kg}$ of air-dried soil were placed on top of this. The soil in the pots was amended with $100 \mathrm{mg} \mathrm{N} \mathrm{kg}^{-1}$ as urea, $50 \mathrm{mg} \mathrm{P} \mathrm{kg}^{-1}$ as $\mathrm{KH}_{2} \mathrm{PO}_{4}$, and $125 \mathrm{mg} \mathrm{K} \mathrm{kg}^{-1}$ as $\mathrm{KH}_{2} \mathrm{PO}_{4}$ and $\mathrm{K}_{2} \mathrm{SO}_{4}$, all of which were applied and mixed evenly with the upper layer of the soil ( $3 \mathrm{~kg}$ of a total of $10 \mathrm{~kg}$ ). The $\mathrm{ZnO}-\mathrm{NPs}$ treatments used in this study were based on applying an average of 3, 20, and $225 \mathrm{mg} \mathrm{Zn} \mathrm{kg}^{-1}$ ( $\mathrm{Zn}$ basis) (i.e. 30, 200, and $2250 \mathrm{mg} \mathrm{Zn} \mathrm{pot}{ }^{-1}$, respectively) as dry $\mathrm{ZnO} \mathrm{NP}$ powder.
Table 1 Main physicochemical parameters and element concentrations measured in acidic and calcareous soils

\begin{tabular}{|c|c|c|}
\hline & Acid soil & Calcareous soil \\
\hline $\mathrm{pH}$ & 5.4 & 8.5 \\
\hline Texture (USDA) & Silt loam & Silty clay loam \\
\hline Sand $\left(\mathrm{g} \mathrm{kg}^{-1}\right)$ & 250 & 175 \\
\hline Silt $\left(\mathrm{g} \mathrm{kg}^{-1}\right)$ & 570 & 435 \\
\hline Clay $\left(\mathrm{g} \mathrm{kg}^{-1}\right)$ & 180 & 390 \\
\hline pHw (1:2.5 w:v) & 5.39 & 8.46 \\
\hline Organic matter $\left(\mathrm{g} \mathrm{kg}^{-1}\right)$ & 16.9 & 11.3 \\
\hline Total carbonate $\left(\mathrm{g} \mathrm{kg}^{-1}\right)$ & nd & 106 \\
\hline Free carbonate $\left(\mathrm{g} \mathrm{kg}^{-1}\right)$ & nd & 24 \\
\hline E.C. $(\mu \mathrm{S} / \mathrm{cm})(1: 5 \mathrm{w}: \mathrm{v})$ & 66.9 & 125.9 \\
\hline Available P (mg kg $\left.{ }^{-1}\right)$ & 10.7 & 16.05 \\
\hline Base saturation $\left(\mathrm{g} \mathrm{kg}^{-1}\right)$ & 54.7 & 100 \\
\hline C.E.C (cmolc/kg) & 11.4 & 22.1 \\
\hline Total N (g kg-1) & 0.91 & 0.90 \\
\hline $\mathrm{C} / \mathrm{N}$ ratio & 13.3 & 10.9 \\
\hline Total Fe $\left(\mathrm{mg} \mathrm{kg}^{-1}\right)$ & $14,515 \pm 246$ & $14,600 \pm 329$ \\
\hline Total $\mathrm{Cu}\left(\mathrm{mg} \mathrm{kg}^{-1}\right)$ & $9.6 \pm 0.2$ & $24.5 \pm 0.8$ \\
\hline Total Mn ( $\left.\mathrm{mg} \mathrm{kg}^{-1}\right)$ & $518 \pm 19$ & $162 \pm 3$ \\
\hline Total $\mathrm{Zn}\left(\mathrm{mg} \mathrm{kg}^{-1}\right)$ & $40 \pm 2$ & $62 \pm 3$ \\
\hline
\end{tabular}

E.C. electrical conductivity, C.E.C cation exchange capacity

Nontreated soils were used as controls to assess whether $\mathrm{ZnO}$ NPs treatments could have affected plant growth. These treatments were subsequently excluded from the statistical analysis used to test the effectiveness of the soil extraction tests for assessing both $\mathrm{Zn}$ bioaccumulation patterns in the plants and leaching to groundwater as they did not reveal any effects associated with the recent addition of $\mathrm{Zn}$ from ZnO-NPs. The application rate of $3 \mathrm{mg} \mathrm{Zn} \mathrm{kg-1} \mathrm{was} \mathrm{very}$ low, but it was tested to reflect realistic conditions of $\mathrm{ZnO}$ NPs in polluted natural soils ((Tiede et al. 2009). The application rate of $20 \mathrm{mg} \mathrm{Zn} \mathrm{kg}^{-1}$ was selected because it is a typical $\mathrm{Zn}$ rate applied to soils when conventional $\mathrm{Zn}$ oxide (microparticulate) is used as a fertilizer. A maximum application rate of $225 \mathrm{mg} \mathrm{Zn} \mathrm{kg}^{-1}$ was chosen, based on information about the effects of ZnO-NPs on numerous plant species recently reported in the literature (Raliya 2015; Bandyopadhyay et al. 2015; Zuverza-Mena et al. 2017). Often, but not always, concentrations of less than 200-250 $\mathrm{mg} \mathrm{Zn} \mathrm{kg}^{-1}$, such as ZnO NPs, have been shown to have beneficial effects on plant growth, whereas higher concentrations have occasionally produced inhibitory effects, according to NP size, soil type, and plant species.

All the $\mathrm{ZnO}$-NPs applications were mixed into the upper layer of the soil in the pots (at an approximate soil depth of 0 $8 \mathrm{~cm}$ ). Three replicates were used for each treatment, with a 
total of 48 lysimeters in a randomized arrangement. After $72 \mathrm{~h}$ of interaction following the $\mathrm{Zn}$ treatments applied to the soil, two plant species, common bean (Phaseolus vulgaris L. cv. Contender) and cherry tomato (Solanum lycopersicum L. cv. Cerasiforme), were grown from seed in the containers in an uncontrolled greenhouse environment on the campus of Universidad Politécnica de Madrid (Spain) until the edible parts of both crops (tomato fruits and green beans, respectively) were ready for harvesting. Temperatures ranged from 4 to $38{ }^{\circ} \mathrm{C}$ and relative humidity from 20 to $85 \%$. The soils were irrigated with tap water, to slightly above the field capacity moisture level, in order to obtain various portions of leachate throughout the whole plant life-cycle (five portions were obtained for the bean crop and six portions for the tomato crop); we collected a total volume of $400 \mathrm{~mL}$ from each of them. These leachates were collected approximately once every 10 12 days. The leachates were collected with a silicone tube leading to a polyethylene recipient. The green beans (unripe fruits of the bean plant) and cherry tomato fruits were gradually collected and washed in deionized water. The green beans were then dried to a constant weight in a force-draft oven at $60{ }^{\circ} \mathrm{C}$, and the tomato fruits were vacuum freeze-dried. After the tomato and bean crops had been harvested (60 and 90 days after germination for bean and tomato, respectively), soil samples were taken from the upper layer of the soil in the pots (from depths of approximately $0-8 \mathrm{~cm}$ ) as this is the area of plant root development.

The harvested plants were washed in deionized water and then the different vegetative parts (roots, stems, and leaves) were separated and their fresh weights recorded. The plant roots were then cut off and washed in deionized water in an ultrasound-assisted bath at $35 \mathrm{kHz}$ for $15 \mathrm{~min}$. To desorb $\mathrm{Zn}$ from the plant root surfaces, the roots were washed with $10 \mathrm{mmol} \mathrm{L}^{-1} \mathrm{Na}_{4}$ EDTA for $15 \mathrm{~min}$, using an ultrasonic treatment at $35 \mathrm{kHz}$ (Zhou et al. 2011). Finally, all plant samples were dried to a constant weight in a force-draft oven at $60{ }^{\circ} \mathrm{C}$.

\subsection{Zinc Concentrations in Soil, Leachates, and Plant Material}

\subsubsection{Total Zn Analyses of Soils, Leachates, and Plants}

Total $\mathrm{Zn}$ in the soil samples was determined after treating a $1 \mathrm{~g}$ dried sample with an acid mixture of $\mathrm{HNO}_{3}: \mathrm{HF}$ :double deionized water $(1: 1: 1)$ followed by digestion in Teflon bombs, in a sample preparation block system (SPB Probe, Perkin-Elmer). Total concentrations of trace metals in soil, extracted by strong acids, have been used in the legislation of many countries for the determination of trace metal maximum permissible concentrations in soil (Directive 86/278/EEC 1986).

Two certified reference soils were used to verify the quality of the results for the total $\mathrm{Zn}$ content. These were provided by the Institute for Reference Materials and Measurements of the European Commission (ERM-CC141 and BCR-143R).

The different leachate portions collected in the lysimeters during the experiment were filtered (Whatman no. 41) and acidified with $\mathrm{HNO}_{3}$, and their $\mathrm{Zn}$ contents were then determined. The total amounts of $\mathrm{Zn}$ leached over the whole plant life-cycle of both irrigated crops were then calculated as the sum of the total $\mathrm{Zn}$ content leached $(\mathrm{mg})$ from each of the portions obtained.

The total $\mathrm{Zn}$ concentrations in the dry matter (DM) from the roots, stems, leaves, and fruits harvested from each lysimeter were determined by wet digestion using an acid mixture of $\mathrm{HNO}_{3}: \mathrm{HCl}$ :double-deionized water $(1: 1: 1)$ in Teflon bombs.

The total $\mathrm{Zn}$ concentration in all of the extracts obtained was determined using flame/graphite furnace atomic absorption spectrometry depending on the $\mathrm{Zn}$ concentration ranges involved (AAnalyst 700, Perkin-Elmer).

\subsubsection{Zinc Extraction in Soils}

The soil samples were collected after harvest (60 and 90 days after germination for bean and tomato, respectively). The incubation periods for the ZnO NPs interaction with soil therefore corresponded to approximately 60 and 90 days, respectively, depending on the crop.

The DGT technique and five other commonly used extraction methods involving chemical-extraction media of different strengths (water, $\mathrm{CaCl}_{2}$, LMWOAs, $\mathrm{NH}_{4} \mathrm{OAc}$, and DTPA) were used to assess the extractability of $\mathrm{Zn}$ from $\mathrm{ZnO} \mathrm{NP}$ amended soils: (i) WS: double-deionized water for $2 \mathrm{~h}$ using a soil-to-water ratio of 1:10. After extraction, the soil suspension was centrifuged (4500 rpm, $15 \mathrm{~min}$ ) and the supernatant obtained was filtered through $0.22 \mu \mathrm{m}$ cellulose acetate paper; (ii) $\mathrm{CaCl}_{2}: 2 \mathrm{~g}$ of dried soil mixed with $20 \mathrm{~mL}$ of $0.01 \mathrm{M} \mathrm{CaCl}_{2}$ solution and shaken for $2 \mathrm{~h}$ (Houba et al. 2000); (iii) LMWOAs (rhizosphere-based extraction method): $2 \mathrm{~g}$ of soil in $20 \mathrm{~mL}$ of a mixture of LMWOAs - a 10-mM combination of organic acid solution containing acetic, lactic, citric, malic, and formic acids - in a molar ratio of 4:2:1:1:1, respectively (Feng et al. 2005b); (iv) $\mathrm{NH}_{4} \mathrm{OAc}$ solution 1 Mat $\mathrm{pH}=7$ : the soil solution (2.5:25) was shaken for $2 \mathrm{~h}$ (Van Reeuwijk 2002); (v) DTPA-TEA: DTPA: $5 \times 10^{-3} \mathrm{M}$ diethylene triaminepentaacetic acid (DTPA), $0.01 \mathrm{M} \mathrm{CaCl}_{2}$, and $0.1 \mathrm{M}$ triethanolamine (TEA), adjusted to $\mathrm{pH}$ 7.3. For the extraction, $10 \mathrm{~g}$ of soil were suspended in $20 \mathrm{~mL}$ of the DTPA-TEA extractant solution and shaken for $2 \mathrm{~h}$ (Lindsay and Norvell 1978).

A DGT device was also used to determine diffusive fluxes of $\mathrm{Zn}$ in soil and to derive pore water $\mathrm{Zn}$ concentrations (Degryse et al. 2009). The DGT device consisted of a $\mathrm{Zn}^{2+}$ binding layer (a cation exchange resin: Chelex $100 \mathrm{gel}$, $0.4 \mathrm{~mm}$ thick), and another layer that permits diffusion of the solutes prior to binding, known as the diffusion layer 
(APA gel: a polyacrylamide diffusive gel with an agarose derivate of $0.78 \mathrm{~mm}$ thick). It also incorporated an overlying protective polyethersulphone filter membrane through which ions and NPs can freely diffuse. These layers are permeable to the cations and dissolved complexes that diffuse through them. The $\mathrm{ZnO}$ NPs can pass through the open pore diffusive layer used in standard DGT devices and be retained by the binding resin layer (Pouran et al. 2014). The binding gels and diffusive gels were provided by DGT Research Ltd. (Lancaster, UK). Soil samples of between 80 and $100 \mathrm{~g}$ were placed on plates. Milli-Q water was then added to keep the water content at $70 \%$ of the water holding capacity (WHC), and the plates were sealed with parafilm. After $24 \mathrm{~h}$ of incubation in the dark at $20^{\circ} \mathrm{C}$, each sample was divided into three. The DGT device was then placed on each soil sample and gently pressed down to ensure complete contact between the filter membrane of the device and the soil. The samples with the DGTs were then incubated in the dark at $20^{\circ} \mathrm{C}$ for $24 \mathrm{~h}$. The temperature was recorded throughout the deployment. Upon retrieval of the DGT devices, these were rinsed with Milli-Q water. The binding gels were then removed and eluted with $1 \mathrm{~mL}$ of $1 \mathrm{M} \mathrm{HNO}_{3}$, for at least $24 \mathrm{~h}$, prior to analysis of the soil extract. The results were used to calculate the $\mathrm{C}_{\mathrm{DGT}}$, which is the time averaged $\mathrm{Zn}$ concentration in solution at the interface between the soil and the DGT according to:

$\mathrm{C}_{\text {DGT }}=\frac{M \Delta_{\mathrm{g}}}{D t A}$

where: $\Delta_{\mathrm{g}}$ is the thickness of the diffusive gel $(0.78 \mathrm{~mm})$ plus the thickness of the filter membrane $(0.14 \mathrm{~mm}) ; D$ is the diffusion coefficient of the metal in the gel (diffusion coefficient of $\mathrm{Zn}$ at $\left.20^{\circ} \mathrm{C}=5.2910^{-6} \mathrm{~cm}^{2} \mathrm{~s}^{-1}\right)$; $t$ is the deployment time; and $A$ is the area of exposure $\left(A=2.54 \mathrm{~cm}^{2}\right)$.

The mass $(M)$ of the $\mathrm{Zn}$ accumulated by the DGT sampling device could therefore be calculated using the following equation:

$M=\frac{C_{\mathrm{e}}\left(V_{\mathrm{HNO} 3}+V_{\mathrm{gel}}\right)}{\mathrm{fe}}$

where: $C_{\mathrm{e}}$ is the concentration of $\mathrm{Zn}$ in the $1 \mathrm{M} \mathrm{HNO}_{3}$ elution solution (in $\mu \mathrm{g} \mathrm{L}^{-1}$ ); $V_{\mathrm{HNO} 3}$ is the volume of $\mathrm{HNO}_{3}$ added to the resin gel $(1 \mathrm{~mL}) ; V_{\text {gel }}$ is the volume of the resin gel $(0.16 \mathrm{~mL})$; and fe is the elution factor for each metal $(0.8 \mathrm{to} \mathrm{Zn})$.

The total $\mathrm{Zn}$ concentration in all of the soil extracts obtained was determined using flame/graphite furnace atomic absorption spectrometry, with this depending on the $\mathrm{Zn}$ concentration range (Perkin-Elmer, AAnalyst 700).

\subsection{Statistical Analysis}

Descriptive, simple regression analyses and other statistical studies were made using Statgraphics Centurion XVII 17.2 software (Manugistic, Rockville, MD). Log-transformed data were used in order to follow a normal or near normal distribution (Y-axis) and make the data more uniform (X-axis), thus meeting the two assumptions of normal distribution and uniform variance.

We studied the linear relationships between the different $\log$ - $\mathrm{Zn}$ concentrations in all soil extracts (chemical and DGT) and (i) the log-Zn concentrations in all the different plant parts and (ii) the log-total amount of leached $\mathrm{Zn}$. Firstly, we studied these relationships by combining data for both soils. We then studied these relationships again, but this time including soil type (acidic vs calcareous soil) as a categorical variable. Considering that soil characteristics could influence the model fit of the different soil extraction methods, we compared the constants (or intercepts) and slope coefficients in the regression models.

According to the log-transformation used, $\mathrm{Zn}$ concentration in the different plant parts can be estimated by:

$y=10^{\beta_{0}+\beta_{1} \log (x)}$

where: $\beta_{0}$ is the intercept; $\beta_{1}$ the slope coefficient; and the variable $x$ is the obtained soil extract (LMWOAs, $\mathrm{CaCl}_{2}$, DTPA-TEA, WS, $\mathrm{NH}_{4} \mathrm{Ac}$ or DGT-Zn).

To complete the study, a principal component analyses (PCA) biplot was constructed, which considered two variables: (i) the concentration of $\mathrm{Zn}$ in the different parts (root, stem, leaf, and edible part) of each plant specie and (ii) the soil extractable $\mathrm{Zn}$ amounts (Zn-DTPA-TEA, $\mathrm{Zn}-\mathrm{NH}_{4} \mathrm{Ac}, \mathrm{Zn}$ LMWOAs, $\mathrm{Zn}-\mathrm{CaCl}_{2}$, Zn-WS, and Zn-DGT).

\section{Results}

\subsection{Relationships Between Soil Extractable Zn Concentrations and $\mathrm{Zn}$ Concentrations in Plant Tissues}

In order to find an appropriate extraction method to estimate $\mathrm{Zn}$ concentrations in the different plant tissues (root, stem, leaf, and edible part) of cherry tomato and navy bean, we studied the Pearson correlation coefficients $(r)$ for the relationships between $\mathrm{Zn}$ concentrations in these different plant tissues and the soil extractable $\mathrm{Zn}$ concentrations. In the acidic soil, plant growth was only inhibited with respect to the control treatment (un-spiked soil) for cherry tomato and navy bean at the highest $\mathrm{ZnO}$ NPs rate $\left(225 \mathrm{mg} \mathrm{Zn} \mathrm{kg}^{-1}\right)$ when it significantly affected the germination rate and both the fresh and dry matter yields. Furthermore, the tomato plants exposed to this $\mathrm{ZnO}$ NPs treatment did not survive beyond 15 days. As a consequence, the data relating to the treatment applied to this soil were not taken into account. In contrast, in the calcareous soil, there was no mortality, and the ZnO NPs did not 
significantly $(P>0.05)$ inhibit any of the growth and development parameters for any of the treatments studied.

Bearing in mind the fact that plant species have a key influence on $\mathrm{Zn}$ availability and $\mathrm{Zn}$ uptake in $\mathrm{ZnO} \mathrm{NP}$-amended soils, we studied the Pearson correlation coefficients $(r)$ between $\mathrm{Zn}$ concentrations in all the soil extracts (LMWOAs, $\mathrm{CaCl}_{2}$, DTPA-TEA, WS, $\mathrm{NH}_{4} \mathrm{Ac}$, and DGT) and those found in all the plant tissues (Table 2). In general, the correlations between soil extractable $\mathrm{Zn}$ concentrations and $\mathrm{Zn}$ concentrations in the different plant parts were strongest when using the LMWOAs and $\mathrm{CaCl}_{2}$ methods $(0.817<r<0.988)$, positive, and highly significant $(0.001<P<0.0001)$. The relationships obtained for soil extractable $\mathrm{Zn}$ concentrations with the WS, $\mathrm{NH}_{4} \mathrm{Ac}$, or DGT approaches and $\mathrm{Zn}$ concentrations found in the different plant tissues (root, stem, leaf, and edible part) were strong $(0.608<r<0.915)$, positive, and significant $(0.05<P<0.0001)$. In contrast, significant correlations were only found between $\mathrm{Zn}$ concentration extracted by the DTPATEA method and $\mathrm{Zn}$ concentration in the different parts of cherry tomato and in stem of common bean. These correlations were positive and lower $(0.526<r<0.716 ; P<0.05)$ than those obtained with the other extraction methods.

\subsection{Influence of Soil Type}

Given the possibility that the characteristics of the soil could also influence the fit of the model, we studied a new regression model including soil type (acidic vs calcareous) as a categorical variable. In this new regression model, we obtained the constants (or intercepts) and the slope coefficients of the two different categories (soil type). Figures 1 and 2 show the relationships between $\mathrm{Zn}$ concentration in plant tissues and $\mathrm{Zn}$ concentration in all the soil extracts (LMWOAs, $\mathrm{CaCl}_{2}$, DTPA-TEA, WS, $\mathrm{NH}_{4}$ Ac, and DGT). When soil type was significant for the intercept and/or the slope in the new regression model, its $P$ and $R$-squared values are reported in the corresponding model (see Figs. 1 and 2). The residual standard error (RSE), intercept $\left(\beta_{0}\right)$, and slope $\left(\beta_{1}\right)$ of the linear relationships between $\mathrm{Zn}$ concentrations in the soil extracts and those found in the different plant tissues in both types of regression model (both soils studied conjointly or including soil type as a categorical variable) are available in the Supplementary data.

\subsubsection{Chemical Extraction Methods}

The relationships between $\mathrm{Zn}$ concentration in plant tissues and the LMWOAs-extractable $\mathrm{Zn}$ for each plant species showed that soil type was significant for the intercept and/or the slope only for stem $\mathrm{Zn}$ concentration in cherry tomato and leaf $\mathrm{Zn}$ concentration in common bean. In these cases, the $R$ squared value improved with respect to noninclusion of soil type as a categorical variable. In addition, both $\mathrm{Zn}$ concentrations in plant tissues and soil extractable $\mathrm{Zn}$ concentrations were significantly higher for the acidic soil than for the calcareous one within the range of $\mathrm{ZnO}$ NP concentrations studied.

Significantly different slopes in the regression models that depended on soil type were observed for $\mathrm{Zn}$ concentrations accumulated in stem of cherry tomato and leaf of common bean, while significantly different intercepts, depending on soil type, were also observed in the regression models obtained for leaf of common bean (Figs. 1 and 2).

Table 2 Pearson correlation coefficients $(r)$ between log-transformed values of the $\mathrm{Zn}$ concentrations in different plant tissues and $\mathrm{Zn}$-extractable concentrations from all the ZnO NP-amended soils (both soils studied conjointly)

\begin{tabular}{|c|c|c|c|c|c|c|}
\hline & Zn-LMWOAs & $\mathrm{Zn}-\mathrm{CaCl}_{2}$ & Zn-DTPA-TEA & Zn-WS & $\mathrm{Zn}-\mathrm{NH}_{4} \mathrm{Ac}$ & Zn-DGT \\
\hline \multicolumn{7}{|c|}{ Cherry tomato $(n=15)$} \\
\hline Root & $0.901 * * *$ & $0.916 * * *$ & $0.640 *$ & $0.753^{*}$ & $0.750 *$ & $0.809 * * *$ \\
\hline Stem & $0.941 * * *$ & $0.847 * *$ & $0.716^{*}$ & $0.835 * *$ & $0.851 * *$ & $0.820 * *$ \\
\hline Leaf & $0.956 * * *$ & $0.918 * * *$ & $0.641 *$ & $0.830 * *$ & $0.789 * *$ & $0.915 * * *$ \\
\hline Edible part ${ }^{\mathrm{a}}$ & $0.938 * * *$ & $0.817 * *$ & $0.691 *$ & $0.860 * * *$ & $0.846^{* *}$ & $0.860 * * *$ \\
\hline \multicolumn{7}{|c|}{ Common bean $(n=15)$} \\
\hline Root & $0.936 * * *$ & $0.942 * * *$ & 0.388 & $0.861 * *$ & $0.608 *$ & $0.892 * * *$ \\
\hline Stem & $0.983 * * *$ & $0.988 * * *$ & $0.526^{*}$ & $0.882 * * *$ & $0.719 *$ & $0.906 * * *$ \\
\hline Leaf & $0.845 * *$ & $0.862 * *$ & 0.529 & $0.817 * *$ & $0.687 *$ & $0.839 * *$ \\
\hline Edible part ${ }^{\mathrm{a}}$ & $0.862 * * *$ & $0.860 * * *$ & 0.352 & $0.825 * *$ & 0.503 & $0.787 * *$ \\
\hline
\end{tabular}

Zn-LMWOAs low-molecular-weight organic acids, Zn-DTPA-TEA, DTPA diethylene triaminepentaacetic acid, TEA triethanolamine, Zn-WS water soluble, $Z n-D G T$ diffuse gradients in thin films technique

${ }^{\text {a }}$ Edible part refers to tomato fruits and green beans

$* * *, * *$, and $*$ denote significance at $0.0001,0.001$, and 0.05 , respectively 


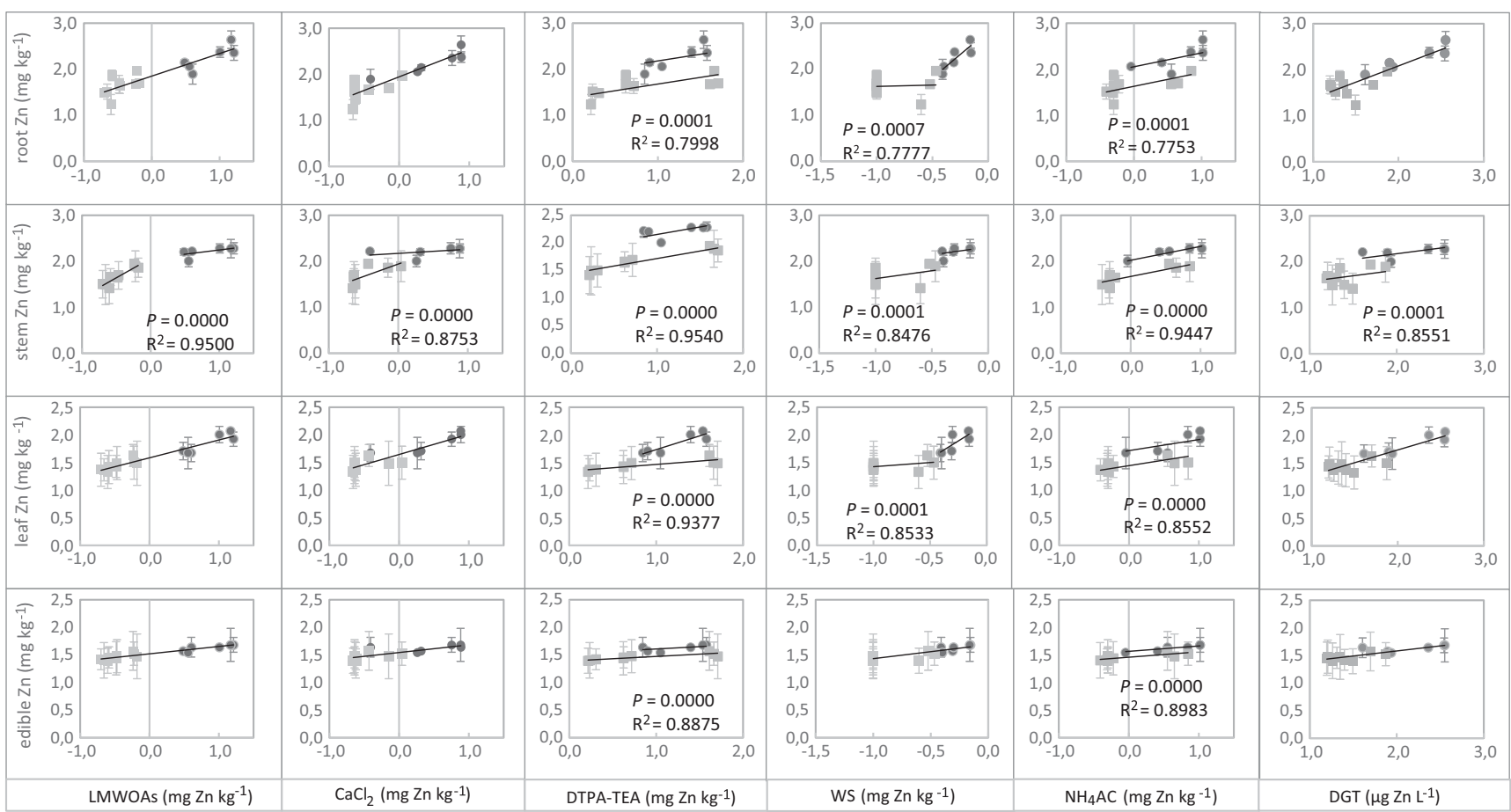

Fig. 1 Linear relationships between the log-transformed values of both the LMWOAs- (low-molecular-weight organic acids), $\mathrm{CaCl}_{2}$, DTPATEA- (DTPA: diethylene triaminepentaacetic acid, TEA: triethanolamine), WS- (water soluble), $\mathrm{NH}_{4}$-acetate-, and DGT (diffuse gradients in thin films technique) -extractable $\mathrm{Zn}\left(\mathrm{mg} \mathrm{Zn} \mathrm{kg}^{-1}\right.$ ) and $\mathrm{Zn}$ concentration in plant tissues (root, stem, leaf, or edible part, $\mathrm{mg} \mathrm{Zn} \mathrm{kg}^{-1}$ )

for cherry tomato. The $P$ and $R$-squared values are reported when soil type, considered as a categorical variable, is significant for the intercept and/or slope (this model is represented with two different continuous lines - acidic vs calcareous soil). Circles and squares represent values from acidic and calcareous soil, respectively $(n=15)$

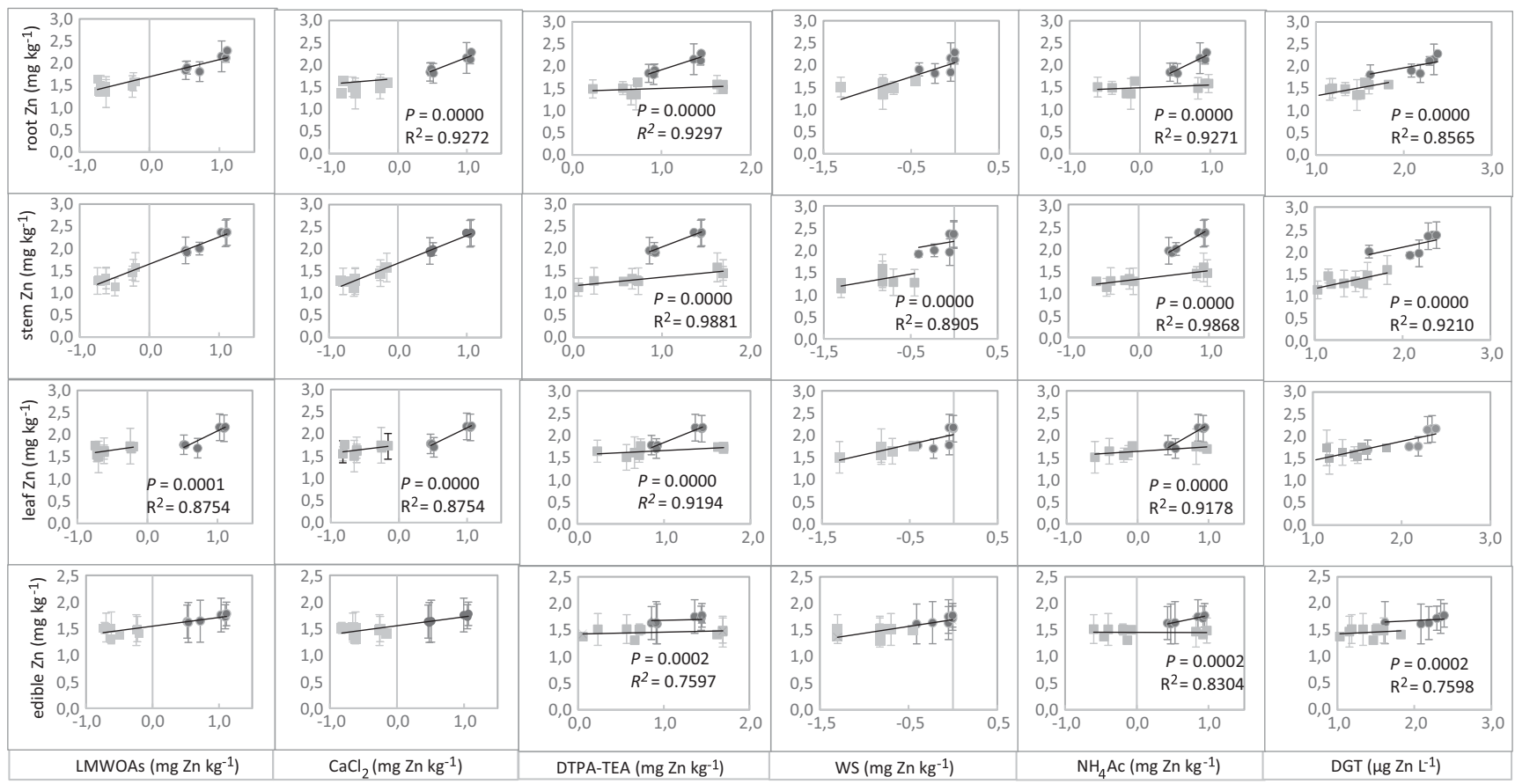

Fig. 2 Linear relationships between the log-transformed values of both the LMWOAs- (low-molecular-weight organic acids), $\mathrm{CaCl}_{2}-$, DTPATEA- (DTPA: diethylene triaminepentaacetic acid, TEA: triethanolamine), WS- (water soluble), $\mathrm{NH}_{4}$-acetate-, and DGT (diffuse gradients in thin films technique) -extractable $\mathrm{Zn}\left(\mathrm{mg} \mathrm{Zn} \mathrm{kg}^{-1}\right)$ and $\mathrm{Zn}$ concentration in plant tissues (root, stem, leaf, or edible part, $\mathrm{mg} \mathrm{Zn} \mathrm{kg}^{-1}$ ) for common bean. The $P$ and $R$-squared values are reported when soil type, considered as a categorical variable, is significant for the intercept and/or slope (this model is represented with two different continuous lines - acidic vs calcareous soil). Circles and squares represent values from acidic and calcareous soil, respectively $(n=15)$ 
The regression study between $\mathrm{CaCl}_{2}$-extractable $\mathrm{Zn}$ concentrations and $\mathrm{Zn}$ concentrations in plant tissues (Figs. 1 and 2) showed that soil type was significant for the intercept and/ or slope for stem $\mathrm{Zn}$ concentration in cherry tomato and root or leaf $\mathrm{Zn}$ concentration in common bean. The $\mathrm{Zn}$ concentrations in stem tissues of cherry tomato were significantly higher for the acidic than for the calcareous soil for the same soil extractable $\mathrm{Zn}$ concentration. In contrast, the common bean models showed both $\mathrm{Zn}$ concentrations in plant tissues and soil extractable $\mathrm{Zn}$ concentrations, which were significantly higher for the acidic soil than for the calcareous soil. Significantly different intercepts in the regression models that depended on soil type were also observed for $\mathrm{Zn}$ concentrations accumulated in stem of cherry tomato and leaf of common bean (Figs. 1 and 2). Significantly different slopes were obtained in the regression models between $\mathrm{CaCl}_{2}$-extractable $\mathrm{Zn}$ and $\mathrm{Zn}$ concentrations accumulated in stem of cherry tomato and root or leaf of common bean.

The relationships obtained between $\mathrm{Zn}$ concentrations extracted from soils with DTPA-TEA and those found in the different plant parts (root, stem, leaf, and edible part) showed that soil type was significant for the intercept and/or the slope in all plant parts and in both plant species (Figs. 1 and 2). Moreover, the $R$-squared values increased with respect to noninclusion of soil type as a categorical variable from $0.277-$ 0.513 to $0.800-0.988$. Significantly different intercepts in the regression models that depended on soil type were observed for all tissues and both plant species. Within the range of $\mathrm{ZnO}$ NP concentrations studied, the $\mathrm{Zn}$ concentrations in plant tissues were significantly greater for the acidic soil than for the calcareous soil for the same soil extractable $\mathrm{Zn}$ concentration. These results could indicate that this reagent extracts more $\mathrm{Zn}$ concentration in calcareous soil than is actually available for the plant, overestimating this concentration. On the other hand, significantly different slopes in the regression models that depended on soil type were observed for all plant parts for leaf in cherry tomato and in common bean (except the edible part) (Figs. 1 and 2). These slopes were much greater for the acidic than for the calcareous soil in all cases. These results indicate greater differences in $\mathrm{Zn}$ concentration in plant tissues for the same changes in DTPA-TEA-extractable $\mathrm{Zn}$ in the acidic soil than in the calcareous one.

The regression study between WS-extractable $\mathrm{Zn}$ in soil and $\mathrm{Zn}$ concentration in the different plant tissues (Figs. 1 and 2) shows that soil type was significant for the intercept and/or the slope for vegetative tissue $\mathrm{Zn}$ concentration of cherry tomato (root, stem, and leaf) and stem $\mathrm{Zn}$ concentration in common bean. There was also an improvement in the $R$ squared values in these linear relationships, especially in cherry tomato (from $0.567-0.689$ to $0.778-0.853$ ). In all these cases, both $\mathrm{Zn}$ concentrations in plant tissues and soil extractable $\mathrm{Zn}$ concentrations were significantly higher for the acidic soil than for the calcareous one. Significantly different intercepts that depended on soil type were observed in all these regression models (Table 2). Significantly different slopes that depended on soil type were only obtained in the regression analysis between WS-extractable $\mathrm{Zn}$ and $\mathrm{Zn}$ concentration accumulated in cherry tomato root and leaf.

The regression study between $\mathrm{NH}_{4} \mathrm{Ac}$-extractable $\mathrm{Zn}$ in soil and $\mathrm{Zn}$ concentration in plant tissues showed that soil type was significant for the intercept and/or the slope in all plant parts and all plant species. Also, the regression models obtained when including soil type as a categorical variable gave better $R$-squared values than when using the data for both soils conjointly, in all plant species and plant tissues studied. Interestingly, for the two plant species, $\mathrm{Zn}$ concentrations in the different plant tissues were significantly higher for the acidic soil than for the calcareous one, for the same $\mathrm{NH}_{4} \mathrm{Ac}$ extractable $\mathrm{Zn}$ concentration. Significantly different intercepts in the regression models that depended on soil type were observed for all $\mathrm{Zn}$ concentrations accumulated in plant tissues except for root of common bean. In addition, significantly different slopes were obtained in the regression models between $\mathrm{NH}_{4} \mathrm{Ac}$-extractable $\mathrm{Zn}$ and $\mathrm{Zn}$ concentrations in common bean (Fig. 2).

\subsubsection{DGT Technique}

Figures 1 and 2 also show the relationships between the soil extractable $\mathrm{Zn}$ concentrations obtained using the DGT technique ( $\mathrm{Zn}-\mathrm{DGT}$ ) and the $\mathrm{Zn}$ concentrations in the different plant tissues (root, stem, leaf, and edible part) for tomato and common bean, respectively. The regression study between $\mathrm{Zn}$-DGT in soil and $\mathrm{Zn}$ concentration in the different plant tissues shows that soil type was significant for the intercept and/or the slope for stem $\mathrm{Zn}$ concentration in cherry tomato and root, stem, and edible part $\mathrm{Zn}$ concentration in common bean. It should be noted that these regression models show different intercepts that depended on soil type, but nearly all show the same slope for both soils (Figs. 1 and 2). For both plant species, $\mathrm{Zn}$ concentrations in plant tissues were significantly higher for the acidic than for the calcareous soil, with the log-extractable $\mathrm{Zn}$ concentration values in the soil ranging from 1.61 to 1.87 and from 1.62 to 1.83 , respectively. Also, in these models, the $R$-squared values were higher than when using the data for both soils together. The $R$-squared values increased from $0.619-0.820$ to $0.760-0.921$ (edible part and stem of common bean, respectively).

Considering all the methods used, the best correlation according to the RSE were obtained for edible part: RSE from 0.03 to 0.06 in cherry tomato and RSE from 0.06 to 0.07 in common bean (supplementary data).

To complete this study, a PCA biplot was generated which considered $\mathrm{Zn}$ concentration in the different parts of each plant species and soil extractable $\mathrm{Zn}$ concentration as variables (Fig. 3). The variance explained by the first 2 components 


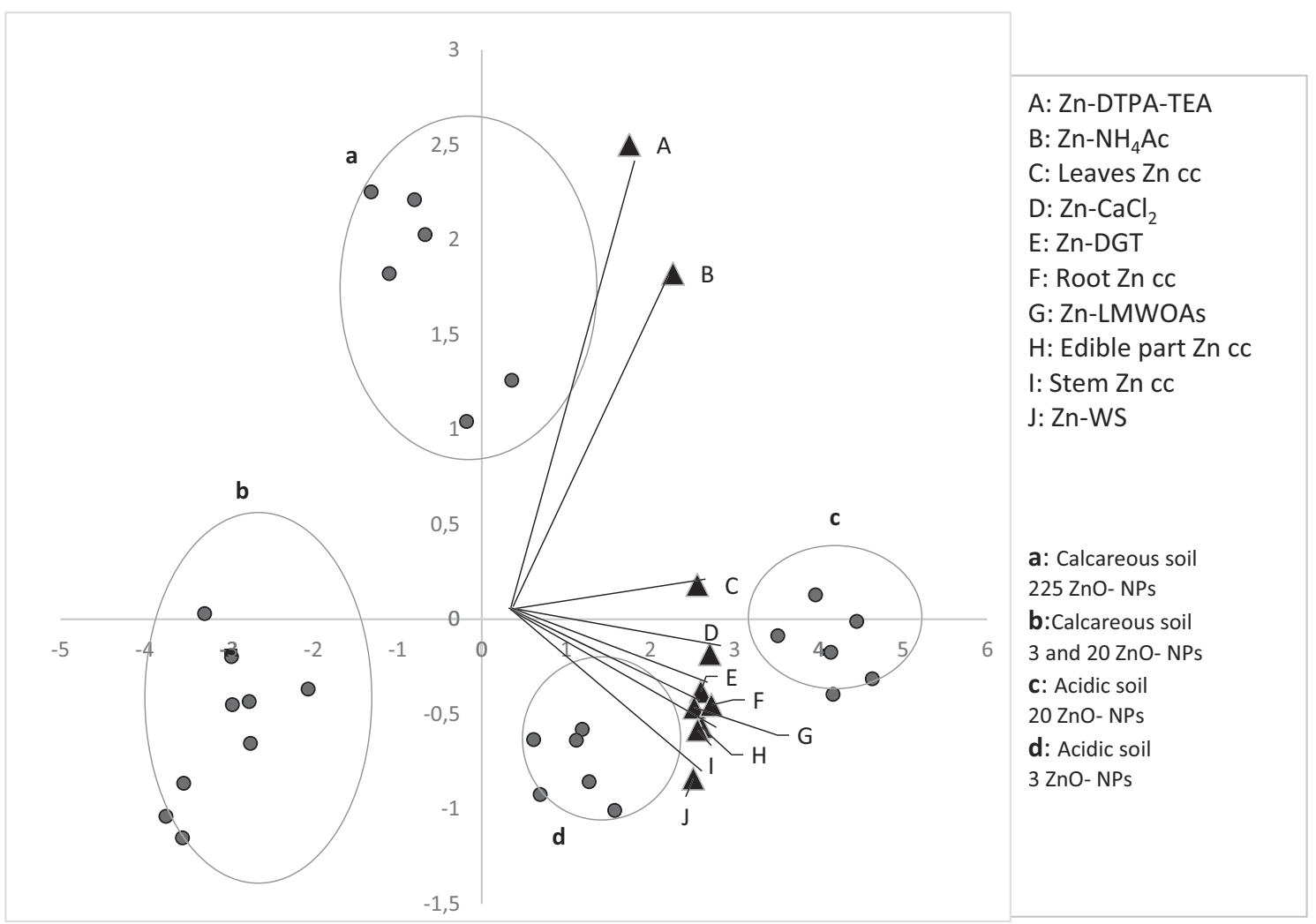

Fig. 3 Biplot of the first two principal components of the principal component analysis (PCA) of soil extractable $\mathrm{Zn}$ concentration [LMWOAs (low-molecular-weight organic acids), $\mathrm{CaCl}_{2}$, DTPA-TEA-
(DTPA: diethylene triaminepentaacetic acid, TEA: triethanolamine), WS(water soluble), $\mathrm{NH}_{4}$-acetate-, and DGT (diffuse gradients in thin films technique)] and $\mathrm{Zn}$ concentration in the different plant tissues was $88.83 \%$ (x-axis $77.96 \%$, y-axis $10.87 \%$ ). In the biplot of the first two components, it is possible to distinguish different groups of values depending on soil type and/or the applied $\mathrm{ZnO}$ NP ratio. The PCA biplot shows that $\mathrm{Zn}$ concentrations were grouped by soil type: calcareous soil to the left of the $\mathrm{x}$ axis and acidic soil to the right of the $\mathrm{x}$-axis. The highest $\mathrm{Zn}$ ratio (225 mg Zn kg${ }^{-1}$ ) in calcareous soil is grouped in the upper left quadrant of the PCA, mainly influenced by $\mathrm{Zn}$ DTPA-TEA. On the other hand, ZnO-NPs-3 and ZnO-NPs20 in the calcareous soil are grouped together in the lower left quadrant of the PCA and could not be differentiated. The $\mathrm{Zn}$ concentration in the acidic soil also formed groups separated according to the applied $\mathrm{Zn}$ ratio.

According to the PCA biplot, $\mathrm{Zn}$ concentrations assessed by DTPA-TEA and $\mathrm{NH}_{4} \mathrm{Ac}$ extractions are fairly close together, indicating a close and positive relationship between them. In contrast, these extraction methods did not appear to be related to the $\mathrm{Zn}$ concentration in root, stem, or edible part of plants since a right angle presumes no correlation between variables. The $\mathrm{CaCl}_{2}$ and, especially, the DGT and LMWOAs methods appear to be related to $\mathrm{Zn}$ concentration in plant root, stem, and edible part of plants. This suggests that these reagents had a similar extraction capacity in these experimental conditions and that they were able to successfully estimate the $\mathrm{Zn}$ concentration in these parts of the plants. The angle in the biplot between $\mathrm{Zn}-\mathrm{WS}$ and the $\mathrm{Zn}$ concentration in the stem and edible part of plants presumes a positive correlation between them. Conversely, this reagent did not appear to be related to $\mathrm{Zn}-\mathrm{NH}_{4} \mathrm{Ac}$ since a right angle presumes no correlation between variables.

\subsection{Relationships Between Soil Extractable Zn Concentrations and Leached $\mathrm{Zn}$}

In order to find an appropriate soil test to assess the amounts of $\mathrm{Zn}$ leached from the soil, we also studied the Pearson correlation coefficients $(r)$ between the $\mathrm{Zn}$-extractability for the soil obtained with all the different extraction procedures (LMWOAs, $\mathrm{CaCl}_{2}$, DTPA-TEA, WS, $\mathrm{NH}_{4} \mathrm{Ac}$, and DGT) and the values of the total amounts of $\mathrm{Zn}$ leached from the diverse lysimeters with the different $\mathrm{ZnO}$ NP treatments, except for those in which there was evidence of the inhibition of plant growth. Statistical correlation analyses performed conjointly for both soils and all plant species $(n=30)$ showed that the relationships between $\mathrm{Zn}$ concentrations extracted from soils using the LMWOAs, WS, DGT, or $\mathrm{CaCl}_{2}$ methods and the amounts of leached $\mathrm{Zn}$ were the strongest, positive, and highly significant $(P<0.0001 ; r=0.877,0,865,0.818$, or 0.760 , respectively). The relationships obtained for the $\mathrm{Zn}$ concentrations extracted from soils with the $\mathrm{NH}_{4} \mathrm{Ac}$ approach 
and the amounts of leached $\mathrm{Zn}$ were strong, positive, and also highly significant $(P<0.001, r=0.592)$. In contrast, the $\mathrm{Zn}$ concentrations extracted by the DTPA-TEA method only weakly correlated with the amounts of leached $\mathrm{Zn}(P<0.05$, $r=0.386$ ). Bearing in mind the fact that plant species could have had a key influence on the amount of $\mathrm{Zn}$ leached from the ZnO NP-amended soils, we compared the constants (intercepts) and slope coefficients in the regression model by including plant species as a categorical variable. This analysis showed the same constants and slopes for both plant species, which showed that there was no significant difference in the amount of leached $\mathrm{Zn}$ between the different crops. Figure 4 shows the relationships between the amounts of leached $\mathrm{Zn}$ and $\mathrm{Zn}$ concentration in all soil extracts obtained for both crops conjointly. The regression models obtained when including soil type as a categorical variable showed better $R$ squared values than when using the data for both soils together. In all these regression models, the amount of leached $\mathrm{Zn}$ or/ and extractable $\mathrm{Zn}$ concentration was significantly higher for the acidic soil than for the calcareous one. The regression models obtained when including soil type as a categorical variable show that soil type was significant for the intercept in all cases. According to the RSE values, the different extraction methods used showed low errors in the correlation (RSE ranging from 0.15 to 0.16 ).

\section{Discussion}

\subsection{Comparison Between Soil Zn Extractability and Zn Bioaccumulation in Plant}

Chemical extraction tests are designed to assess the bioavailability of metals in soils. The $\mathrm{Zn}$ source is obviously a crucial parameter to take into account when validating this type of chemical extraction procedure. Although no single soil test is recognized as a universal approach for evaluating the phytoavailability of metals from soils, it is widely held that using neutral-unbuffered salt solutions offers the most practical and appropriate way to assess metal uptake by

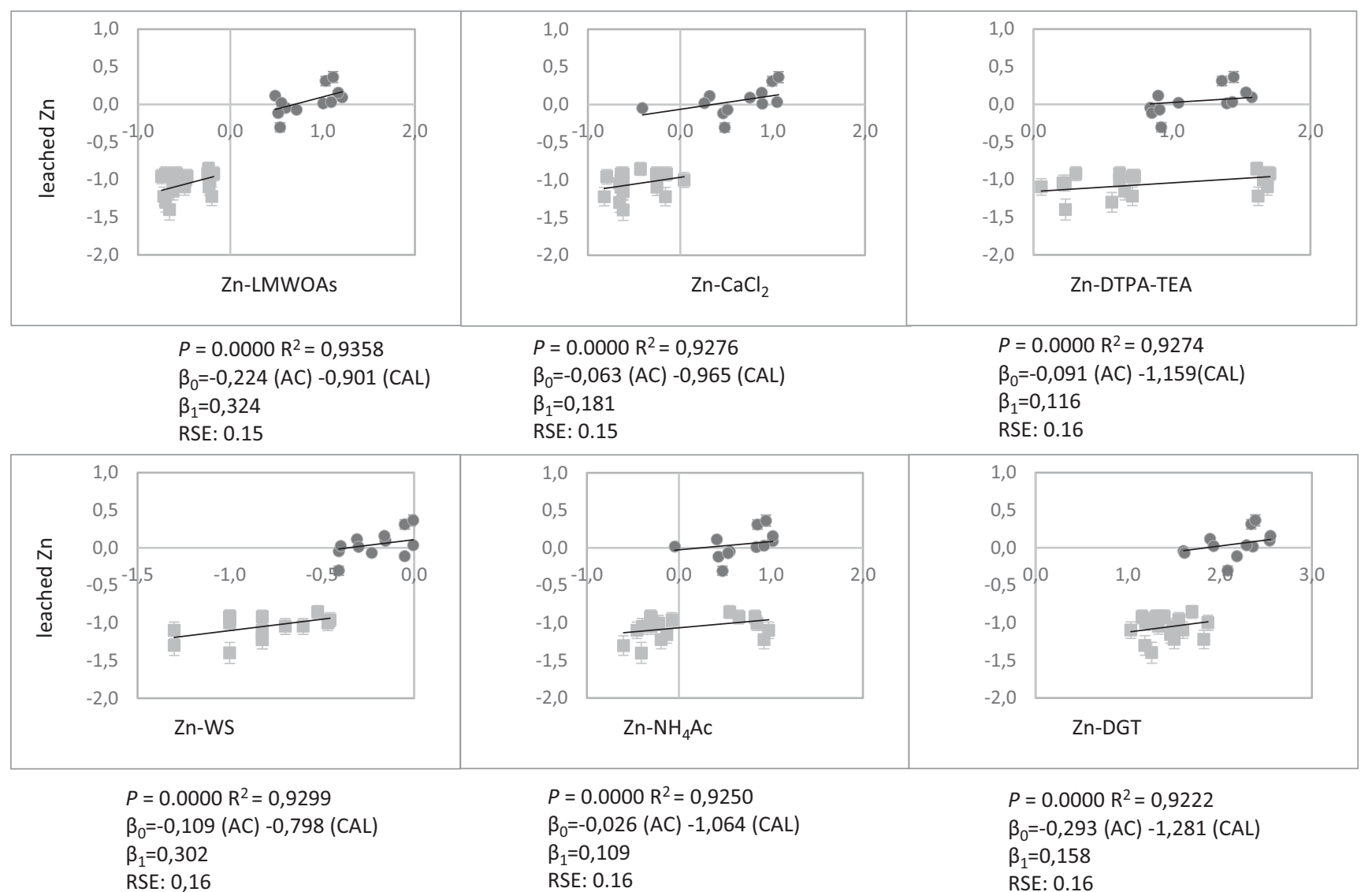

Fig. 4 Linear relationships between the log-transformed values of both the soil extractable $\mathrm{Zn}$ [LMWOAs (low-molecular-weight organic acids), $\mathrm{CaCl}_{2^{-}}$, DTPA-TEA- (DTPA: diethylene triaminepentaacetic acid, TEA: triethanolamine), WS- (water soluble), $\mathrm{NH}_{4}$-acetate-, and DGT (diffuse gradients in thin films technique) -extractable $\mathrm{Zn}, \mathrm{mg} \mathrm{Zn} \mathrm{kg}^{-1}$ ] and leached $\mathrm{Zn}(\mathrm{mg})$ from lysimeters. The $P$ and $R$-squared values are reported when soil type, considered as a categorical variable, is significant for the intercept $-\beta_{0}$ - and/or slope $-\beta_{1}$ - (this model is represented with two different continuous lines - acidic vs calcareous soil). Circles and squares represent values from acidic and calcareous soil, respectively. RSE indicate the residual standard error of the linear relationship(s) $(n=$ 30) 
plants. While many studies have reported the use of neutral salts to be more effective for estimating plant availability than that of more aggressive tests, such as DTPA, there is no general agreement as to which neutral salt solution is the most effective. The use of $0.01 \mathrm{M} \mathrm{CaCl}_{2}$ has been widely promoted in Europe, the USA, New Zealand, and Australia. However, Menzies et al. (2007) concluded that other neutral salt extractants - whether unbuffered (e.g. $0.1 \mathrm{M} \mathrm{NaNO}_{3}$ ) or buffered (e.g. 1.0 $\mathrm{M} \mathrm{NH}_{4} \mathrm{OAc} \mathrm{pH} 7.0$ ) - could provide similar indications of plant available concentrations of metals to the use of $0.01 \mathrm{M} \mathrm{CaCl}_{2}$. These same authors considered that the apparent success of these neutral salt extractants was probably due, at least in part, to the limited number of datasets available for examination in the existing literature.

Various authors have reported that NPs exhibit sorption on exchange sites and that soil parameters largely affect their behavior in the soil by regulating the sorption, dissolution, and aggregation processes (Carbone et al. 2016; Baddar et al. 2019) or by modifying particle surface properties, which may alter $\mathrm{Zn}$ availability to plants (De Santiago-Martin et al. 2015; Meesters et al. 2019). The high reactivity of metalbased NPs resulting from their large surface areas and small sizes could cause their aggregation to similar NPs (homoaggregation) and to natural colloids, which are also present in pore water (hetero-aggregation). Such aggregates could subsequently be retained in the solid matrix, but they could also be subject to dissolution, leading to the release of metal ions, followed by the chemically driven partitioning of the solid phase and solution (Rodrigues et al. 2016). Torrent et al. (2019) concluded that NPs properties (such as their size and coating) would also influence their adsorption processes and the recovery values of the different chemical extraction procedures. The tendencies found could be completely opposite according to the leaching test used and the size of the different NPs. Furthermore, according to other recently published studies (Amooaghaie et al. 2017; Singh et al. 2017; Su et al. 2019), the pattern of metal bioaccumulation in plants grown in soils amended with metal-based NPs may depend on whether or not their metal source is in the form of NPs. In our study, in which ZnO NPs were recently applied to two typical soils of the Mediterranean area, the $\mathrm{Zn}$ bioaccumulation patterns in two plant species (bean and tomato) could be better or worse explained as a function of their $\mathrm{Zn}$ chemical extractability according to the different soil extraction tests, types of soil, plant grown, and/or plant tissue being considered (Table 2). Considering all the results obtained, these findings would seem to be in agreement with those reported in previous studies that involved soils amended with $\mathrm{Zn}$ sources that were not in the form of NPs. These involved what were documented as weak extractions (consisting of water, both diluted and unbuffered salt solutions, and diluted solutions of mild acids), which were used to provide the best relationships between extractable amounts of $\mathrm{Zn}$ in the soils and bioaccumulated
$\mathrm{Zn}$ in both plant species. In contrast, the $\mathrm{NH}_{4} \mathrm{Ac}$ and DTPATEA extraction methods were able to successfully estimate the $\mathrm{Zn}$ concentrations in the edible part of plants in cherry tomato ( $P<0.001$ and $P<0.05$, respectively) but not in common bean $(P>0.05)$ (Table 2). Furthermore, these extraction methods were able to correlate $\mathrm{Zn}$ concentrations in the vegetative parts of the plant (root, stem, and leaf) in the case of cherry tomato $(P<0.05)$, although only $\mathrm{NH}_{4} \mathrm{Ac}$ reagent was able to assess $\mathrm{Zn}$ concentrations in all the vegetative parts of the common bean. All these results indicate that the model fit of the soil test studied depends on plant type. Differences between crops in terms of their root development, the particular characteristics of the different plant species studiedwhich accumulated different $\mathrm{Zn}$ concentrations in their tissues - could explain the differences in the regression models that relate to the soil-plant $\mathrm{Zn}$ concentrations. Amooaghaie et al. (2017) performed a study with ZnO NPs and other $\mathrm{Zn}$ sources applied to tomato and wheat crops and found differences in the levels of $\mathrm{Zn}$ accumulation in the vegetative tissues of both plant species. Singh et al. (2017) reported that the more active accumulation of NPs by tomato plants compared with cauliflower was possibly due to differences in root morphology. In our experiment, the tomato roots had a large surface area as they had numerous thin-walled roots. Moreover, the tomato has a deep-penetrating root system. This suggests that rhizospheric acidification could have caused a strong mobilization of $\mathrm{Zn}$. As a result, more $\mathrm{Zn}$ and/ or $\mathrm{ZnO} N P s$ could have been able to penetrate and accumulate in the root cells of this crop (Su et al. 2019).

The principal component analysis (PCA) showed that the differences between the predictive capacities of the different soil tests studied were also due to differences in the strengths of the different reagents used. Chelating agents (such as DTPA) are strong extractants and can help remove elements from adsorption sites to estimate the potentially mobile $\mathrm{Zn}$ and thus potential bioavailability (Almendros et al. 2015). The $\mathrm{NH}_{4} \mathrm{Ac}$ solution extracts metal ions bonding to soil colloids by ion exchange. The $\mathrm{Zn}$ accumulation patterns in both plant species were poorly explained when buffered chemical extractions, such as DTPA (buffered at $\mathrm{pH} 7.3$ ) or $1.0 \mathrm{M} \mathrm{NH}_{4} \mathrm{OAc}$ (buffered at $\mathrm{pH}$ 7.0), were used. This was particularly true for the common bean. The PCA also showed a close relationship between both buffered soil tests.

According to the ISO 17402 international standard (Harmsen 2008), the available fraction of metals in soils should be divided into several different fractions: an actually available fraction (or the actual amount dissolved at ambient conditions); a potentially available fraction, which is the maximum amount that can be released under certain predefined conditions; and a nonavailable fraction. The potentially available fraction includes the actually available fraction but cannot exceed the total concentration. According to this standard, complexing agents, such as EDTA and DTPA, can simulate 
potentially available concentrations of metals in the soil, which include the fraction sorbed to the soil matrix. The available fraction of metals in the soil is not a fixed fraction because the total exposure of organisms depends on time. As a result, the phytoavailability not only covers the amount of metal in the pore water but may also include the amount that desorbs during the time that the plant is in contact with the soil. The amount of metals in the soil solution represents the most available fraction, and, in addition to this readily available fraction, the plant is also capable of influencing the release of some weakly bound trace metals from the soil rhizosphere. In theory, chemical extractions involving mild extractants (such as water, both diluted and unbuffered salt solutions, and diluted acidic solutions) do the same to remove trace metals from the soil solution and also remove some weakly bound metals. There is, however, no certainty that these methods will always give us accurate estimations of bioavailability since they depend - among other factors - on the plant species or plant genotypes involved, on the soil properties, and on metal speciation in the soil (Alvarez et al. 2006; Cattani et al. 2006; Gonzalez et al. 2007, 2015; Obrador et al. 2007; Almendros et al. 2015). For example, the DTPA extraction method has proved its suitability for assessing $\mathrm{Zn}$ plant uptake in lettuce from ten peri-urban calcareous soils found in the Mediterranean area (De Santiago-Martín et al. 2014), which have physicochemical properties that are similar to the calcareous soil used in this study. They concluded that metal fractions that were estimated a priori as being potentially available could effectively be bioavailable in this type of soil. Similar results were found for barley in neutral and near-alkaline soils (Feng et al. 2005b). In theory, EDTA is a nonspecific extractant and one that can be used to extract both labile and nonlabile fractions. However, the DTPA extraction method could be suitable for calcareous soils as it is buffered at a $\mathrm{pH}$ of 7.3 and minimizes the dissolution of carbonates and the release of occluded metals (Feng et al. 2005a).

The LMWOAs is an extraction method based on the effects of low-molecular-weight organic acid contents in rhizospheric soil, which can dissolve $\mathrm{Zn}$ and promote $\mathrm{Zn}$ uptake by plant roots. Metals extracted by the rhizosphere-based method correspond to the mobile fractions in the soil solution (Naidu and Harter 1998); these are responsible for the short-term available pool (Cieslinski et al. 1998). For its part, $\mathrm{CaCl}_{2}$ is a neutral salt that can only extract from soil exchangeable metals. This extraction method is used to determine readily available nutrient concentrations in solution in a wide range of soils (Houba et al. 2000). The procedure employed is based on equilibrating the soil with a surplus of cations $\left(\mathrm{Ca}^{2+}\right)$, which exchange a certain amount of the metal ions from soil surfaces by competitive adsorption without influencing soil $\mathrm{pH}$. In the biplot of the first two principal components (Fig. 3), the $\mathrm{CaCl}_{2}$, WS, and, especially, the LMWOAs extraction methods appeared to be related to $\mathrm{Zn}$ concentrations in plant root, stem, and edible part. These results could indicate that soil tests involving weak extractants (such as water, $0.01 \mathrm{M} \mathrm{CaCl}_{2}$, and $0.01 \mathrm{M}$ LMWOAs) could be appropriate for assessing $\mathrm{Zn}$ bioaccumulation patterns in tomato and bean plants when $\mathrm{ZnO}$ NPs are applied to typical Mediterranean soils whose physicochemical characteristics are analogous to the two types of soil studied.

Soil characteristics influence $\mathrm{Zn}$ availability to the plant (Cakmak and Kutman 2018). Numerous studies performed with traditional sources of $\mathrm{Zn}$ have reported that soil characteristics, such as high $\mathrm{pH}$ or $\mathrm{CaCO}_{3}$ concentration, cause $\mathrm{Zn}$ immobilization due to the formation of hydroxides and carbonates and the adsorption of Zn to clay (Lindsay 1979; Shuman 1991). Medina-Velo et al. (2017) reported that the effects of $\mathrm{ZnO} \mathrm{NMs}$ in bean plants (after 45 days of planting) vary with soil composition. Our results show that, in many cases, the predictive capacities of the different reagents used, and particularly the DTPA-TEA and $\mathrm{NH}_{4} \mathrm{Ac}$ extraction methods, greatly improve when soil type is including as a categorical variable (Figs. 1 and 2). It is known that soil $\mathrm{pH}$ is a key factor in the solubility of $\mathrm{Zn}$. However, its influence on $\mathrm{Zn}$ availability to plants from $\mathrm{ZnO} N \mathrm{NP}$ has, to date, received little attention. Zinc oxides are relatively insoluble in water compared to other $\mathrm{Zn}$ sources as $\mathrm{Zn}$ sulphate, but $\mathrm{ZnO}$ NPs should dissolve faster in the soils and to a greater extent than bulk $\mathrm{ZnO}$ due to the higher specific surface area. In our study with $\mathrm{ZnO}$ NPs, both $\mathrm{Zn}$ concentrations in the different plant parts and the extractability of $\mathrm{Zn}$ when using the LMWOAs, $\mathrm{CaCl}_{2}$, and WS tests were notably higher in the acidic than in the calcareous soil (Figs. 1 and 2). In addition to having quite a high $\mathrm{pH}$, the clay content in the calcareous soil was higher than in the acidic soil. This could also have contributed to the increase in the retention of $\mathrm{ZnO} N P s / \mathrm{Zn}^{2+}$ by the soil and hence to the corresponding decrease in $\mathrm{Zn}$ availability to plants. When using the DTPA-TEA and $\mathrm{NH}_{4} \mathrm{Ac}$ extraction methods, the $\mathrm{Zn}$ concentrations in the different plant parts were higher in the acidic than in the calcareous soil, for the same soil extractable Zn concentration (Figs. 1 and 2). This could have been due to the fact that both reagents extract more $\mathrm{Zn}$ from calcareous soils than is actually available for the plant. According to different authors (Gonzalez et al. 2007; Almendros et al. 2015), extracting agents such as DTPA-TEA applied to calcareous soils results in the extraction of not only the $\mathrm{Zn}$ associated with the water soluble and exchangeable fractions, but also that associated with the carbonate fraction. As a result, there is an overestimation of the potential $\mathrm{Zn}$ availability to plants since the $\mathrm{Zn}$ associated with the carbonate fraction corresponds to a relatively low mobility pool within the soil. The DTPA-TEA method was originally developed to identify micronutrient deficiencies in near neutral and calcareous soils (Lindsay and Norvell 1978). However, in our study in which ZnO NPs were applied, the DTPA-TEA reagent extracted more $\mathrm{Zn}$ than any of the other methods tested, especially from the calcareous soil. Martin 
Soriano-Disla et al. (2010) reported that considerable amounts of metals were released when the DTPA-TEA method was applied and that these were not plant available. Our results with $\mathrm{ZnO}$ NPs were in line with those of Feng et al. (2005b) and Menzies et al. (2007), which suggested that DTPA-TEA is sometimes a poor estimator of plant available metals in soils.

\subsection{Comparison Between Soil Chemical Extractions and the DGT Technique}

Zinc is an essential micronutrient for plants and is taken up via specific transporter proteins on root surfaces. Chemical extraction methods are equilibrium-based methods and do not consider root uptake at the root-soil boundary. These methods have certain disadvantages as it is difficult to prevent the readsorption of metals to the soil phase during chemical extraction and this may have a negative impact on the results obtained. On the other hand, DGT-like the roots themselves - acts as a zero sink for ions. It could therefore be used as a surrogate for trace element uptake by plant roots. DGT also accounts for the replenishment of depleted ions and therefore could also permit the prediction of long-term bioavailability (Puschenreiter et al. 2013). The DGT is permeable to the cations and dissolved complexes, which diffuse thorough them. The ZnO NPs can pass through the open pore diffusive layer used in standard DGT devices and be retained by the binding resin layer (Pouran et al. 2014). In our study, the DGT technique satisfactorily assessed root and shoot concentrations of $\mathrm{Zn}$ from $\mathrm{ZnO}$ NP-amended soils (Table 2). Puschenreiter et al. (2013) also reported good correlations between $\mathrm{Zn}$ concentrations in roots and $\mathrm{Zn}$ concentrations estimated using the DGT approach. In our study, the model fit of $\mathrm{Zn}$ concentration in stem of both plant species and in root and edible part of common bean improved when soil type was included as a categorical variable (Figs. 1 and 2). Miner et al. (1997) also reported that soil properties needed to be included in the best fits to multiple regression models in order to improve the relationships between plant metal concentrations and soil-extractable metals for chemical extraction (EDTA and DTPA). Conversely, Feng et al. (2005a) reported that the equations for the LMWOAs method are the simplest for assessing bioavailability, particularly in comparison with the DTPA, EDTA, $\mathrm{CaCl}_{2}$, and/or $\mathrm{NaNO}_{3}$ reagents. Our results suggest that when the two soils studied were amended with $\mathrm{ZnO} \mathrm{NPs}$, both the weak extractants (LMWOAs, $\mathrm{CaCl}_{2}$, and WS) and DGT technique offered the most robust approaches for evaluating the bioavailability of $\mathrm{Zn}$ to tomato and common bean plants since the fit of the model with the other two extraction methods (DTPA-TEA and $\mathrm{NH}_{4} \mathrm{Ac}$ ) depended on the soil type.

According to the PCA (Fig. 3), the DGT technique and the LMWOAs extraction method were fairly close in $\mathrm{Zn}$ concentration estimations in root, stem, and edible part. This result suggests that both techniques could potentially be used in a similar way to estimate the $\mathrm{Zn}$ amount in these parts of plants from ZnO NPs applied to soil. Also, this PCA show that the DGT technique could potentially be used to estimate very satisfactorily $\mathrm{Zn}$ concentrations not only in root but also in stem and the edible plant parts. Menzies et al. (2007) studied a large data set taken from published papers (although none included soils amended with metal-based NPs). They concluded that equilibrium-based soil metal extraction procedures typically showed poor correlations with shoot metal concentrations. Unlike in the chemical extraction approaches, the DGT technique takes into consideration the kinetic processes that take place between the soil solid and solution phases (Wang et al. 2018), including the resupply of metals from the solid phase to the solution phase (Dai et al. 2018). Small $\mathrm{ZnO}$ NPs can pass through the open pore diffusive layer used in standard DGT devices and can be retained by the binding resin layer (Pouran et al. 2014). Consequently, this technique could be expected to simulate plant uptake in soils amended with $\mathrm{ZnO}$ NPs with a good predictive capacity (Song et al. 2018). However, the results from our study were not in agreement with those reported by different authors (Zhang and Young 2005; Menzies et al. 2007; Degryse et al. 2009) who obtained better correlations between $\mathrm{Zn}$ concentrations in shoots and $\mathrm{Zn}$ concentrations extracted using the DGT technique than when chemical extractions were used. In our study, the LMWOAs, WS, and $\mathrm{CaCl}_{2}$ extraction method and the DGT technique could potentially be used in a similar way to estimate the $\mathrm{Zn}$ amount in the aerial parts (stem, leaf, and edible part) of the plants from ZnO NPs applied to soil (Fig. $3)$.

\subsection{Comparison Between Zn Extractability in Soil and Leached $\mathrm{Zn}$}

The total quantities of $\mathrm{Zn}$ that were leached to groundwater (throughout the whole plant life-cycle) were better or worse explained as functions of $\mathrm{Zn}$-extractability (whether chemical or DGT), with this depending on the soil extraction test used. Overall, and considering all of the results obtained, both the weak chemical extractions (such as water, both diluted and unbuffered salt solutions, and diluted solutions of mild acids) and the DGT technique produced the best relationships between the amounts of extractable $\mathrm{Zn}$ in the soil and the total amounts of leached $\mathrm{Zn}$ from both of the ZnO NPs-amended soils. Thus, either weak chemical extractions or DGT protocols could be used to assess the potential buildup of the total amount of $\mathrm{Zn}$ (particulate plus dissolved) transported to groundwater from $\mathrm{ZnO}$ NPs recently applied to typical soils in Central Spain. In contrast, the total quantities of $\mathrm{Zn}$ leached throughout the whole plant life-cycle were poorly explained when buffered chemical extractions, such as $1.0 \mathrm{M} \mathrm{NH}_{4} \mathrm{OAc}$ (buffered at $\mathrm{pH}$ 7.0) and especially DTPA-TEA (buffered at 
$\mathrm{pH}$ 7.3), were used. When the soil type was considered as a categorical factor, Pearson correlation coefficients also showed a strong, positive correlation between DTPA-TEA- or $\mathrm{NH}_{4} \mathrm{OAc}$-extractable $\mathrm{Zn}$ and the total amount of leached $\mathrm{Zn}$ (Fig. 4). Although the pool of a contaminant present in soil pore water is the most relevant measure that can be used to characterize transport processes in soils, it should be noted that the pool of $\mathrm{Zn}^{2+} / \mathrm{ZnO}-\mathrm{NPs}$ retained in the solid matrix may be potentially mobile as a result of changes in surface chemistry, soil properties... The total amount of $\mathrm{Zn}$ from recently applied $\mathrm{ZnO}$ NPs could therefore be lost to groundwater, as a result of leaching, throughout the life cycle of an irrigated crop. This would comprise of pore water, and, according to the specific environmental conditions, it could also include the amount of $Z n$ released during the time that the plant is in contact with the soil. As time passes, the $\mathrm{ZnO} \mathrm{NP}$ aggregates $/ \mathrm{Zn}^{2+}$ bound to different soil components can be released to the soil solution, which will have a potential impact on groundwater.

It is worthy of note that, for both plant species, there was a big difference between the amounts of leached $\mathrm{Zn}$ in the two soil types (acidic vs calcareous), with best regression models being obtained when soil type was included as a categorical variable. Different authors (Duchaufour 1987; Violante et al. 2010; Gonzalez et al. 2015) have reported that the movement of dissolved micronutrients through the soil profile due to the addition of water is clearly related to both the texture and physicochemical characteristics of the soil.

According to Zhao et al. (2012a, b), bare ZnO NPs also exhibited very limited transport distances and low availability in two natural calcareous soils for short exposure times because most of the NPs were either associated or complexed with various different soil components (most of the $\mathrm{ZnO}$ NPs were associated with carbonate, while a smaller fraction was bound to Fe-Mn oxides and organic fractions) and only a minor amount was both soluble and exchangeable.

When the $\mathrm{NH}_{4} \mathrm{Ac}$ reagent was used the amounts of leached $\mathrm{Zn}$ were higher in the acidic than in the calcareous soil for the same amount of soil extractable $\mathrm{Zn}$. This behavior was also observed when the DTPA-TEA method was employed. This could indicate that these reagents extracted more $\mathrm{Zn}$ concentration in calcareous soil than was leached, overestimating this concentration. Chelating agents like DTPA are strong extractants and remove elements from adsorption sites to estimate the potentially mobile $\mathrm{Zn}$. This reagent could have extracted part of the metal content associated with the soil components, even though their solubility was low.

\section{Conclusions}

The results obtained in this study show that the different extraction methods applied influenced the amounts of $\mathrm{Zn}$ that were extracted from the $\mathrm{ZnO}$ NP-amended soils. Both for tomato and for common bean, it was possible to successfully predict the $\mathrm{Zn}$ concentrations in the roots and aerial parts of plants (stems, leaves, and edible parts) using the diffusive gradient in thin films (DGT) technique and weak chemical extractions: diluted solutions of mild acids-low-molecularweight organic acids, LMWOAs, neutral-unbuffered salt solutions - $\mathrm{CaCl}_{2}$, or water-WS. Moreover, in these cases, the prediction of the $\mathrm{Zn}$ concentration in the different plant tissues only slightly improved when the soil type was considered as a categorical factor. Our results suggest that when the two soils studied were amended with ZnO NPs, both the weak extractants (LMWOAs, $\mathrm{CaCl}_{2}$, and WS) and DGT technique offered the most robust approaches for evaluating the bioavailability of $\mathrm{Zn}$ to these plant species since the equations with the other two extraction methods (DTPA-TEA and $\mathrm{NH}_{4} \mathrm{Ac}$ ) are depending on the soil type. In this study, the physical-chemical properties of the calcareous soil, especially in terms of both its high $\mathrm{pH}$ and clay content, contributed to increasing the soil retention of $\mathrm{ZnO} \mathrm{NPs} / \mathrm{Zn}^{2+}$ and hence the corresponding decrease in $\mathrm{Zn}$ availability to plants. Overall, although the weak chemical extraction and DGT technique were able to estimate the total quantities of $\mathrm{Zn}$ that were leached to groundwater - throughout the whole-life cycles of both irrigated crops-, the correlation improved in all cases when the soil type was included as a categorical variable.

Acknowledgments The authors are grateful to Pilar Ortiz and Javier Sanchez for the technical assistance provided. English language editing and review services supplied by MJH Translation.

Funding Information This study was funded by the Spanish projects RTA2013-00091-C02-01/-02 and FEDER funds.

\section{Compliance with Ethical Standards}

Conflict of Interest The authors declare that they have no conflict of interest.

Abbreviations CEC, Cation exchange capacity; DGT, Diffuse gradients in thin films; DM, Dry matter; DTPA, Diethylene triaminepentaacetic acid; LMWOAs, Low-molecular-weight organic acids; NP, Nanoparticles; PCA, Principal component analyses; RSE, Residual standard error; TEA, Triethanolamine; TEM, Transmission electron microscope; WS, Water-soluble

\section{References}

Adhikari T, Kundu S, Biswas AK, Tarafdar JC, Rao AS (2015) Characterization of zinc oxide nanoparticles and their effect on growth of maize (Zea mays L.) plant. J Plant Nutr 38:1505-1515. https://doi.org/10.1080/01904167.2014.992536

Adisa IO, Pullagurala VLR, Peralta-Videa JR, Dimkpa CO, Elmer WH, Gardea-Torresdey JL, White JC (2019) Recent advances in nanoenabled fertilizers and pesticides: a critical review of mechanisms of 
action. Environ Sci-Nano 6:2002-2030. https://doi.org/10.1039/ c9en $00265 \mathrm{k}$

Allison LE, Moodie CD (1965) Carbonate. Methods of Soil Analysis Part 2 Chemical and Microbiological Properties 1379-1396

Almendros P, Obrador A, Gonzalez D, Alvarez JM (2015) Biofortification of zinc in onions (Allium cepa L.) and soil $\mathrm{Zn}$ status by the application of different organic $\mathrm{Zn}$ complexes. Sci Hortic $186: 254-265$

Alvarenga P, Laneiro C, Palma P, de Varennes A, Cunha-Queda C (2013) A study on $\mathrm{As}, \mathrm{Cu}, \mathrm{Pb}$ and $\mathrm{Zn}$ (bio)availability in an abandoned mine area (Sao Domingos, Portugal) using chemical and ecotoxicological tools. Environ Sci Pollut Res 20:6539-6550. https://doi.org/ 10.1007/s11356-013-1649-2

Alvarenga P, Simoes I, Palma P, Amaral O, Matos JX (2014) Field study on the accumulation of trace elements by vegetables produced in the vicinity of abandoned pyrite mines. Sci Total Environ 470:12331242. https://doi.org/10.1016/j.scitotenv.2013.10.087

Alvarez JM, Lopez-Valdivia LM, Novillo J, Obrador A, Rico MI (2006) Comparison of EDTA and sequential extraction tests for phytoavailability prediction of manganese and zinc in agricultural alkaline soils. Geoderma 132:450-463. https://doi.org/10.1016/j. geoderma.2005.06.009

Amooaghaie R, Norouzi M, Saeri M (2017) Impact of zinc and zinc oxide nanoparticles on the physiological and biochemical processes in tomato and wheat. Botany 95:441-455. https://doi.org/10.1139/ cjb-2016-0194

Antisari LV, Carbone S, Gatti A, Vianello G, Nannipieri P (2013) Toxicity of metal oxide ( $\mathrm{CeO} 2, \mathrm{Fe} 3 \mathrm{O} 4, \mathrm{SnO} 2)$ engineered nanoparticles on soil microbial biomass and their distribution in soil. Soil Biol Biochem 60:87-94. https://doi.org/10.1016/j.soilbio.2013.01.016

Baddar ZE, Matocha CJ, Unrine JM (2019) Surface coating effects on the sorption and dissolution of $\mathrm{ZnO}$ nanoparticles in soil. Environ SciNano 6:2495-2507. https://doi.org/10.1039/c9en00348g

Bala R, Kalia A, Dhaliwal SS (2019) Evaluation of efficacy of ZnO nanoparticles as remedial zinc Nanofertilizer for Rice. J Soil Sci Plant Nutr 19:379-389. https://doi.org/10.1007/s42729-01900040-z

Bandyopadhyay S, Plascencia-Villa G, Mukherjee A, Rico CM, JoseYacaman M, Peralta-Videa JR, Gardea-Torresdey JL (2015) Comparative phytotoxicity of $\mathrm{ZnO} \mathrm{NPs}$, bulk $\mathrm{ZnO}$, and ionic zinc onto the alfalfa plants symbiotically associated with Sinorhizobium meliloti in soil. Sci Total Environ 515:60-69. https://doi.org/10. 1016/j.scitotenv.2015.02.014

Bastani S, Hajiboland R, Khatamian M, Saket-Oskoui M (2018) Nano iron $(\mathrm{Fe})$ complex is an effective source of $\mathrm{Fe}$ for tobacco plants grown under low Fe supply. J Soil Sci Plant Nutr 18:524-541

Bower CA, Reitemeier RF, Fireman M (1952) Exchangeable cation analysis of saline and alkali soils. Soil Sci 73:251-262

Bremner JM (1996) Nitrogen-total. Methods of soil analysis part 3chemical methods 1085-1121

Cakmak I, Kutman UB (2018) Agronomic biofortification of cereals with zinc: a review. Eur J Soil Sci 69:172-180. https://doi.org/10.1111/ ejss. 12437

Carbone S, Hertel-Aas T, Joner EJ, Oughton DH (2016) Bioavailability of $\mathrm{CeO} 2$ and $\mathrm{SnO} 2$ nanoparticles evaluated by dietary uptake in the earthworm Eisenia fetida and sequential extraction of soil and feed. Chemosphere 162:16-22. https://doi.org/10.1016/j.chemosphere. 2016.07.044

Cattani I, Fragoulis G, Boccelli R, Capri E (2006) Copper bioavailability in the rhizosphere of maize (Zea mays L.) grown in two Italian soils. Chemosphere 64:1972-1979

Cieslinski G, Van Rees KCJ, Szmigielska AM, Krishnamurti GSR, Huang PM (1998) Low-molecular-weight organic acids in rhizosphere soils of durum wheat and their effect on cadmium bioaccumulation. Plant Soil 203:109-117. https://doi.org/10.1023/A: 1004325817420
Cristina S, Arruda C, Luiz A, Silva D, Moretto R, Antunes R, Aurélio M, Arruda Z (2015) Nanoparticles applied to plant science : a review. Talanta 131:693-705. https://doi.org/10.1016/j.talanta.2014.08.050

Dai Y, Nasir M, Zhang Y, Gao J, Lv Y, Lv J (2018) Comparison of DGT with traditional extraction methods for assessing arsenic bioavailability to Brassica chinensis in different soils. Chemosphere 191: 183-189. https://doi.org/10.1016/j.chemosphere.2017.10.035

Davison W, Zhang H (1994) In-situ speciation measurements of trace components in natural-waters using thin-film gels. Nature 367: $546-548$

Day PR (1965) 'Particle fractionation and particle-size analysis.' (American Society of Agronomy, Soil Science Society of America)

De Santiago-Martín A, Valverde-Asenjo I, Quintana JR, Vázquez A, Lafuente AL, González-Huecas C (2014) Carbonate, organic and clay fractions determine metal bioavailability in periurban calcareous agricultural soils in the Mediterranean area. Geoderma 221-222: 103-112. https://doi.org/10.1016/j.geoderma.2014.01.009

De Santiago-Martin A, Constantin B, Guesdon G, Kagambega N, Raymond S, Cloutier RG (2015) Bioavailability of engineered nanoparticles in soil systems. J Hazard Toxic Radioactive Waste 20: B4015001

Degryse F, Smolders E, Zhang H, Davison W (2009) Predicting availability of mineral elements to plants with the DGT technique: a review of experimental data and interpretation by modelling. Environ Chem 6:198-218. https://doi.org/10.1071/EN09010

Directive 86/278/EEC (1986) 'Protection of the environment, and in particular of the soil, when sewage sludge is used in agriculture'

Duchaufour P (1987) Manual de edafologia. Masson, Barcelona, Spain. Manual de edafologia Masson, Barcelona, Spain

Ebbs SD, Bradfield SJ, Kumar P, White JC, Musante C, Ma X (2016) Accumulation of zinc, copper, or cerium in carrot (Daucus carota) exposed to metal oxide nanoparticles and metal ions. Environ SciNano 3:114-126. https://doi.org/10.1039/c5en00161g

El Hadri H, Louie SM, Hackley VA (2018) Assessing the interactions of metal nanoparticles in soil and sediment matrices - a quantitative analytical multi-technique approach. Environ Sci-Nano 5:203-214. https://doi.org/10.1039/c7en00868f

FAO (2015) 'Base referencial mundial del recurso suelo. Sistema internacional de clasificación de suelos.' (Organización de las Naciones Unidas para la Alimentación y la Agricultura, Ed.). (Organización de las Naciones Unidas para la Alimentación y la Agricultura: Roma) http://www.fao.org

Feng MH, Shan XQ, Zhang SZ, Wen B (2005a) Comparison of a rhizosphere-based method with other one-step extraction methods for assessing the bioavailability of soil metals to wheat. Chemosphere 59:939-949. https://doi.org/10.1016/j.chemosphere. 2004.11.056

Feng MH, Shan X, Zhang S, Wen B (2005b) A comparison of the rhizosphere-based method with DTPA, EDTA, $\mathrm{CaCl} 2$, and NaNO3 extraction methods for prediction of bioavailability of metals in soil to barley. Environ Pollut 137:231-240. https://doi. org/10.1016/j.envpol.2005.02.003

García-Gómez C, Obrador A, González D, Babín M, Fernández MD (2017) Comparative effect of $\mathrm{ZnO}$ NPs, $\mathrm{ZnO}$ bulk and $\mathrm{ZnSO} 4$ in the antioxidant defences of two plant species growing in two agricultural soils under greenhouse conditions. Sci Total Environ 589: 11-24. https://doi.org/10.1016/j.scitotenv.2017.02.153

Giri PK, Singh DK, Kesavamoorthy R, Panigrahi BK, Nair KGM (2007) Correlating the microstructural and photoluminescence properties of $\mathrm{ZnO}$ nanoparticles prepared by ball milling. Proceedings of the 14th International Workshop on the Physics of Semiconductor Devices, IWPSD 905-908. doi:https://doi.org/10.1109/IWPSD.2007. 4472669

Gomes SIL, Murphy M, Nielsen MT, Kristiansen SM, Amorim MJB, Scott-Fordsmand JJ (2015) Cu-nanoparticles ecotoxicity - explored 
and explained? Chemosphere 139:240-245. https://doi.org/10. 1016/j.chemosphere.2015.06.045

Gonzalez D, Obrador A, Alvarez JM (2007) Behavior of zinc from six organic fertilizers applied to a navy bean crop grown in a calcareous soil. J Agric Food Chem 55:7084-7092

Gonzalez D, Almendros P, Alvarez JM (2015) Mobility in soil and availability to triticale plants of copper fertilisers. Soil Res 53:412-422

Harmsen J (2007) Measuring bioavailability: from a scientific approach to standard methods. J Environ Qual 36:1420-1428. https://doi.org/ $10.2134 /$ jeq2006.0492

Harmsen J (2008) Soil quality-requirements and guidance for the selection and application of methods for the assessment of bioavailability of contaminants in soil and soil materials. Werkgroep ISO/ DIS17402 Soil quality, Genève

Hashimoto Y, Takeuchi S, Mitsunobu S, Ok Y-S (2017) Chemical speciation of silver (Ag) in soils under aerobic and anaerobic conditions: Ag nanoparticles vs. ionic Ag. J Hazard Mater 322:318-324. https:// doi.org/10.1016/j.jhazmat.2015.09.001

Houba VJG, Temminghoff EJM, Gaikhorst GA, van Vark W (2000) Soil analysis procedures using $0.01 \mathrm{M}$ calcium chloride as extraction reagent. Commun Soil Sci Plant Anal 31:1299-1396. https://doi. org/10.1080/00103620009370514

Judy JD, Mcnear DH, Chen C, Lewis RW, Tsyusko OV, Bertsch PM, Stegemeier JP, Lowry GV, Mcgrath SP, Durenkamp M, Unrine JM (2015) Nanomaterials in biosolids inhibit nodulation , shift microbial community composition, and result in increased metal uptake relative to bulk/dissolved metals. Environ Sci Technol. https://doi. org/10.1021/acs.est.5b01208

Karimi A, Moezzi A, Chorom M, Enayatizamir N (2019) Chemical fractions and availability of $\mathrm{Zn}$ in a calcareous soil in response to biochar amendments. J Soil Sci Plant Nutr 19:851-864. https://doi.org/10. 1007/s42729-019-00084-1

Kopittke P, Lombi E, Wang P, Schjørring JK, Husted S (2019) Nanomaterials as fertilizers for improving plant mineral nutrition and environmental outcomes. Environ Sci: Nano. https://doi.org/ 10.1039/C9EN00971J

Lindsay W (1979) In: Lindsay W (ed) Chelate equilibria. 'Chem. Equilibria soils'. John Wiley and Sons, New York, pp 238-263

Lindsay WL, Norvell WA (1978) Development of a DTPA soil test for zinc, iron, manganese, and copper. Soil Sci Soc Am J 42:421-428. https://doi.org/10.2136/sssaj1978.03615995004200030009x

Lock K, Janssen CR (2003) Influence of aging on copper bioavailability in soils. Environ Toxicol Chem 22:1162-1166. https://doi.org/10. 1897/1551-5028(2003)022<1162:IOAOCB >2.0.CO;2

Lv J, Zhang S, Luo L, Zhang J, Yang K, Christie P (2015) Accumulation, speciation and uptake pathway of $\mathrm{ZnO}$ nanoparticles in maize. Environ Sci-Nano 2:68-77. https://doi.org/10.1039/c4en00064a

Lv J, Christie P, Zhang S (2019) Uptake, translocation, and transformation of metal-based nanoparticles in plants: recent advances and methodological challenges. Environ Sci: Nano 6:41-59. https:// doi.org/10.1039/C8EN00645H

Martin Soriano-Disla J, Speir TW, Gomez I, Clucas LM, McLaren RG, Navarro-Pedreno J (2010) Evaluation of different extraction methods for the assessment of heavy metal bioavailability in various soils. Water Air Soil Pollut 213:471-483. https://doi.org/10.1007/ s11270-010-0400-6

Medina-Velo IA, Dominguez OE, Ochoa L, Barrios AC, HernandezViezcas JA, White JC, Peralta-Videa JR, Gardea-Torresdey JL (2017) Nutritional quality of bean seeds harvested from plants grown in different soils amended with coated and uncoated zinc oxide nanomaterials. Environ Sci-Nano 4:2336-2347. https://doi. org $/ 10.1039 / \mathrm{c} 7 \mathrm{en} 00495 \mathrm{~h}$

Meesters JAJ, Peijnenburg WJGM, Hendriks AJ, de Meent D, Quik JTK (2019) A model sensitivity analysis to determine the most important physicochemical properties driving environmental fate and exposure of engineered nanoparticles. Environ Sci-Nano 6:20492060. https://doi.org/10.1039/c9en00117d

Menzies NW, Donn MJ, Kopittke PM (2007) Evaluation of extractants for estimation of the phytoavailable trace metals in soils. Environ Pollut 145:121-130. https://doi.org/10.1016/j.envpol.2006.03.021

Milani N, McLaughlin MJ, Stacey SP, Kirby JK, Hettiarachchi GM, Beak DG, Cornelis G (2012) Dissolution kinetics of macronutrient fertilizers coated with manufactured zinc oxide nanoparticles. J Agric Food Chem 60:3991-3998. https://doi.org/10.1021/jf205191y

Miner GS, Gutierrez R, King LD (1997) Soil factors affecting plant concentrations of cadmium, copper, and zinc on sludge-amended soils. J Environ Qual 26:989-994

Mitrano DM, Mehrabi K, Dasilva YAR, Nowack B (2017) Mobility of metallic (nano)particles in leachates from landfills containing waste incineration residues. Environ Sci-Nano 4:480-492. https://doi.org/ $10.1039 / \mathrm{c} 6 \mathrm{en} 00565 \mathrm{a}$

Montalvo D, Degryse F, da Silva RC, Baird R, McLaughlin MJ (2016) Agronomic effectiveness of zinc sources as micronutrient fertilizer. 'Adv. Agron.' (Ed D Sparks) Advances in Agronomy. pp. 215-267 doi:https://doi.org/10.1016/bs.agron.2016.05.004

Naidu R, Harter RD (1998) Effect of different organic ligands on cadmium sorption by and extractability from soils. Soil Sci Soc Am J 62: 644-650. https://doi.org/10.2136/s s saj 1998 . $03615995006200030014 \mathrm{x}$

Nelson DW, Sommers L (1982) Total carbon, organic carbon, and organic matter 1. Methods of soil analysis Part 2 Chemical and microbiological properties 539-579

Nijensohn L, Pizarro OC (1960) Un procedimiento para la determinación del calcáreo activo en suelos orgánicos. Boletín Técnico 2,

Obrador A, Alvarez JM, Lopez-Valdivia LM, Gonzalez D, Novillo J, Rico MI (2007) Relationships of soil properties with Mn and Zn distribution in acidic soils and their uptake by a barley crop. Geoderma 137:432-443. https://doi.org/10.1016/j.geoderma.2006. 10.001

Olsen SR (1954) Estimation of available phosphorus in soils by extraction with sodium bicarbonate. US Dep Agric Circ 939:1-19

Pandorf M, Pourzahedi L, Gilbertson L, Lowry GV, Herckes P et al (2019) Graphite nanoparticle addition to fertilizers reduces nitrate leaching in growth of lettuce (Lactuca sativa). Environ Sci-Nano Adv Ar. https://doi.org/10.1039/C9EN00890J

Perelshtein I, Lipovsky A, Perkas N, Gedanken A, Moschini E, Mantecca $\mathrm{P}$ (2015) The influence of the crystalline nature of nano-metal oxides on their antibacterial and toxicity properties. Nano Res 8:695-707. https://doi.org/10.1007/s12274-014-0553-5

Pouran HM, Martin FL, Zhang H (2014) Measurement of ZnO nanoparticles using diffusive gradients in thin films: binding and diffusional characteristics. Anal Chem 86:5906-5913. https://doi.org/10.1021/ ac500730s

Poynton HC, Chen C, Alexander SL, Major KM, Blalock BJ, Unrine JM (2019) Enhanced toxicity of environmentally transformed $\mathrm{ZnO}$ nanoparticles relative to $\mathrm{Zn}$ ions in the epibenthic amphipod Hyalella azteca. Environ Sci-Nano 6:325-340. https://doi.org/10. 1039/c8en00755a

Puschenreiter M, Wittstock F, Friesl-Hanl W, Wenzel WW (2013) Predictability of the $\mathrm{Zn}$ and cd phytoextraction efficiency of a Salix smithiana clone by DGT and conventional bioavailability assays. Plant Soil 369:531-541. https://doi.org/10.1007/s11104-013$1597-0$

Raliya NC (2015) Mechanistic evaluation of translocation and physiological impact of titanium dioxide and zinc oxide nanoparticles on the tomato (Solanum lycopersicum L.) plant. Metallomics 7:1584-1594

Rauret G (1998) Extraction procedures for the determination of heavy metals in contaminated soil and sediment. Talanta 46:449-455

Rizwan M, Ali S, Farooq M, Sik Y, Adrees M, Ibrahim M, Zia-ur-rehman M, Farid M, Abbas F (2017) Effect of metal and metal oxide nanoparticles on growth and physiology of globally important food crops 
: a critical review. J Hazard Mater 322:2-16. https://doi.org/10.1016/ j.jhazmat.2016.05.061

Rodrigues SM, Trindade T, Duarte AC, Pereira E, Koopmans GF, Romkens PFAM (2016) A framework to measure the availability of engineered nanoparticles in soils: trends in soil tests and analytical tools. TrAC - Trends Anal Chemistryrends Anal Chem 75:129-140. https://doi.org/10.1016/j.trac.2015.07.003

Rutkowska B, Szulc W, Bomze K, Gozdowski D, Spychaj-Fabisiak E (2015) Soil factors affecting solubility and mobility of zinc in contaminated soils. Int J Environ Sci Technol 12:1687-1694. https:// doi.org/10.1007/s13762-014-0546-7

Sekine R, Brunetti G, Donner E, Khaksar M, Vasilev K, Jämting ÅK, Scheckel KG, Kappen P, Zhang H, Lombi E (2014) Speciation and lability of Ag-, $\mathrm{AgCl}-$, and $\mathrm{Ag} 2 \mathrm{~S}$-nanoparticles in soil determined by X-ray absorption spectroscopy and diffusive gradients in thin films. Environ Sci Technol 49:897-905

Servin AD, White JC (2016) Nanotechnology in agriculture: next steps for understanding engineered nanoparticle exposure and risk. NanoImpact 1:9-12. https://doi.org/10.1016/j.impact.2015.12.002

Shuman L (1991) Chemical forms of micronutrients in soils. 'Micronutr. Agric.' (Ed LWR Mortvedt, JJ; Cox, FR; Shuman) pp. 113-144. (Soil Science Society of America: Madison, WI)

Singh A, Singh NB, Hussain I, Singh H (2017) Effect of biologically synthesized copper oxide nanoparticles on metabolism and antioxidant activity to the crop plants Solanum lycopersicum and Brassica oleracea var. botrytis. J Biotechnol 262:11-27. https://doi.org/10. 1016/j.jbiotec.2017.09.016

Soil Survey Staff (2014) Keys to soil taxonomy, Twelfth Edition. United States Department of Agriculture Natural Resources Conservation Service 360

Song Z, Shan B, Tang W (2018) Evaluating the diffusive gradients in thin films technique for the prediction of metal bioaccumulation in plants grown in river sediments. J Hazard Mater 344:360-368. https://doi. org/10.1016/j.jhazmat.2017.10.049

Su Y, Ashworth V, Kim C, Adeleye AS, Rolshausen P, Roper C, White J, Jassby D (2019) Delivery, uptake, fate, and transport of engineered nanoparticles in plants: a critical review and data analysis. Environ Sci-Nano 6:2311-2331. https://doi.org/10.1039/c9en00461k

Tiede K, Hassellöv M, Breitbarth E, Chaudhry Q, Boxall ABA, Hutton S, Yo Y (2009) Considerations for environmental fate and ecotoxicity testing to support environmental risk assessments for engineered nanoparticles. J Chromatogr A 1216:503-509. https://doi.org/10. 1016/j.chroma.2008.09.008

Tombuloglu H, Slimani Y, Alshammari T, Tombuloglu G, Almessiere M, Baykal A, Ercan I, Ozcelik S, Demirci T (2019) Magnetic behavior and nutrient content analyses of barley (Hordeum vulgare L.) tissues upon $\mathrm{CoNd} 0.2 \mathrm{Fe} 1.8 \mathrm{O} 4$ magnetic nanoparticle treatment. J Soil Sci Plant Nutr in press. https://doi.org/10.1007/s42729-019-00115-x

Torrent L, Margui E, Queralt I, Hidalgo M, Iglesias M (2019) Interaction of silver nanoparticles with mediterranean agricultural soils: labcontrolled adsorption and desorption studies. J Environ Sci (China) 83:205-216. https://doi.org/10.1016/j.jes.2019.03.018

Tortella G, Navas M, Parada M, Duran N, Seabra AB, Hoffmann N, Rubilar O (2019) Synthesis of silver nanoparticles using extract of weeds and optimized by response surface methodology to the control of soil pathogenic Bacteria Ralstonia solanacearum. J Soil Sci Plant Nutr 19:148-156. https://doi.org/10.1007/s42729-019-00021-

Van Reeuwijk LP (2002) Procedures for soil analysis. International Soil Reference and Information Centre, Technical Paper

Violante A, Cozzolino V, Perelomov L, Caporale AG, Pigna M (2010) Mobility and bioavailability of heavy metals and metalloids in soil environments. J Soil Sci Plant Nutr 10:268-292. https://doi.org/10. 4067/S0718-95162010000100005

Wang P, Menzies NW, Dennis PG, Guo J, Forstner C, Sekine R, Lombi E, Kappen P, Bertsch PM, Kopittke PM (2016) Silver nanoparticles entering soils via the wastewater-sludge-soil pathway pose low risk to plants but elevated cl concentrations increase ag bioavailability. Environ Sci Technol 50:8274-8281. https://doi.org/10.1021/acs.est. $6 \mathrm{~b} 01180$

Wang J, Zeng X, Zhang H, Li Y, Zhao S, Su S, Bai L, Wang Y, Zhang T (2018) Effect of exogenous phosphate on the lability and phytoavailability of arsenic in soils. Chemosphere 196:540-547. https://doi.org/10.1016/j.chemosphere.2017.12.191

Zhang H, Young SD (2005) Characterizing the availability of metals in contaminated soils. II The soil solution. Soil Use Manag 21:459 467. https://doi.org/10.1079/SUM2005349

Zhao L, Peralta-Videa JR, Hernandez-Viezcas JA, Hong J, GardeaTorresdey JL (2012a) Transport and retention behavior of $\mathrm{ZnO}$ nanoparticles in two natural soils: effect of surface coating and soil composition. J Nano Res 17:229-242. https://doi.org/10.4028/ www.scientific.net/JNanoR.17.229

Zhao L, Peralta-videa JR, Ren M, Varela-ramirez A, Li C, Hernandezviezcas JA, Aguilera RJ, Gardea-torresdey JL (2012b) Transport of $\mathrm{Zn}$ in a sandy loam soil treated with ZnO NPs and uptake by corn plants : Electron microprobe and confocal microscopy studies. Chem Eng J 184:1-8. https://doi.org/10.1016/j.cej.2012.01.041

Zhao L, Zhang H, White JC, Chen X, Li H, Qu X, Ji R (2019) Metabolomics reveals that engineered nanomaterial exposure in soil alters both soil rhizosphere metabolite profiles and maize metabolic pathways. Environ Sci-Nano 6:1716-1727. https://doi.org/10.1039/ c9en00137a

Zhou D, Jin S, Li L, Wang Y, Weng N (2011) Quantifying the adsorption and uptake of $\mathrm{CuO}$ nanoparticles by wheat root based on chemical extractions. J Environ Sci 23(11):1852-1857. https://doi.org/10. 1016/S1001-0742(10)60646-8

Zuverza-Mena N, Martinez-Fernandez D, Du W, Hernandez-Viezcas JA, Bonilla-Bird N, Lopez-Moreno ML, Komarek M, Peralta-Videa JR, Gardea-Torresdey JL (2017) Exposure of engineered nanomaterials to plants: insights into the physiological and biochemical responsesa review. Plant Physiol Biochem 110:236-264. https://doi.org/10. 1016/j.plaphy.2016.05.037

Publisher's note Springer Nature remains neutral with regard to jurisdictional claims in published maps and institutional affiliations. 